\title{
Clinical Significance of miR-210 and its Prospective Signaling Pathways in Non- Small Cell Lung Cancer: Evidence from Gene Expression Omnibus and the Cancer Genome Atlas Data Mining with 2763 Samples and Validation via Real-Time Quantitative PCR
}

\author{
Rong-quan He ${ }^{a}$ Wei-luan Cen ${ }^{a} \quad$ Jie-mei Cen ${ }^{a}$ Wei-ning Cen ${ }^{a} \quad$ Jia-yi Lia \\ Mei-wei Li ${ }^{a} \quad$ Ting-qing Gan ${ }^{b}$ Xiao-hua Hua Gang Chen ${ }^{c}$ \\ aDepartment of Medical Oncology, First Affiliated Hospital of Guangxi Medical University, Nanning \\ Guangxi, Zhuang Autonomous Region, b Department of Medical Oncology, Second Affiliated Hospital \\ of Guangxi Medical University, Nanning, Guangxi, Zhuang Autonomous Region, 'Department \\ of Pathology, First Affiliated Hospital of Guangxi Medical University, Nanning, Guangxi, Zhuang \\ Autonomous Region, China
}

\section{Key Words}

Nsclc $・$ MiR-210 $・$ RT-qPCR $・$ Diagnosis $・$ Prognosis $・$ Bioinformatics

\begin{abstract}
Background/Aims: Since the function of microRNA (miR)-210 in non-small cell lung cancer (NSCLC) remains unclear, we aimed to explore the clinical significance of miR-210 in NSCLC. Methods: NSCLC-related data from 1673 samples on Gene Expression Omnibus and 1090 samples on The Cancer Genome Atlas were obtained and analyzed. The expression level of miR-210 was validated via real-time quantitative PCR analysis with 125 paired clinical samples. A meta-analysis was performed to generate a comprehensive understanding of miR-210 expression and its clinical significance in NSCLC. In addition, bioinformatics analysis was also conducted to reveal the potential underlying mechanism of miR-210 action in NSCLC. Results: miR-210 expression was consistently elevated in NSCLC solid tissue samples. However, its expression was controversial in easily obtained body fluids (i.e., blood, plasma, and serum). Moreover, an overall pooled meta-analysis implied a comparatively higher level of miR-210 expression in NSCLC cancerous tissue than in normal control tissue $(P<0.001)$. In addition, a meta-analysis of outcome revealed a significant diagnostic capacity of miR-210 in NSCLC by detecting its expression in serum and sputum (area under the summary receiver operating

R.-Q. He and W.-L. Cen contributed equally to this work.

\footnotetext{
Gang Chen Department of Pathology, First Affiliated Hospital, Guangxi Medical University,

and Xiao-hua Hu Department of Medical Oncology, the First Affiliated Hospital of Guangxi Medical University (China)

and Xiao-hua Hu Tel. 0086-771-5356534,0086-771-5312980,E-Mail chen_gang_triones@163.com, gxmuhxh@163.com
}

\section{KARGER}




\section{Cellular Physiology Cell Physiol Biochem 2018;46:925-952 \\ \begin{tabular}{l|l} 
DOI: 10.1159/000488823 & $\begin{array}{l}\text { O 2018 The Author(s). Published by S. Karger AG, Basel } \\
\text { www.karger.com/cpb }\end{array}$ \\
\hline
\end{tabular}}

He et al.: Clinical Value of MicroRNA-210 in NSCLC

characteristic curve 0.82 and 0.81 , respectively). miR-210 overexpression was associated with poor progression-free survival (PFS) in NSCLC and was negatively related to overall survival and disease-free survival. Bioinformatic gene enrichment and annotation analyses showed that the target genes of miR-210 were greatly enriched in cell adhesion and plasma membrane, and three pathways were considered to be the main functional circuits of miR-210: renin secretion, the CGMP-PKG signaling pathway, and cell adhesion molecules. Conclusion: In NSCLC, miR-210 expression was elevated and overexpression indicated poor PFS. Expression level of miR-210 in serum and sputum showed significant diagnostic value for NSCLC.

(C) 2018 The Author(s)

Published by S. Karger AG, Base

\section{Introduction}

Lung cancer, comprising the main two types of non-small cell lung cancer (NSCLC) and small cell lung cancer, is the primary cause of malignant tumor-related mortality worldwide, the incidence of which is continuing to increase. The three main classifications of NSCLCsquamous cell carcinoma, adenocarcinoma, and large cell carcinoma-account for $80 \%$ $85 \%$ of all cases of lung cancer [1]. In 2017, there were 222, 500 and 155, 870 estimated new lung cancer cases and deaths, respectively, and the overall 5-year survival rate was $18 \%$ [2]. The low survival rate is mainly due to diagnosis at a late stage, with the 5-year survival rate being only $4 \%$ in such patients [2]. Hence, the early diagnosis and treatment of lung cancer is imperative and also challenging. Despite all of the advances of recent years, there is still a large number of patients with lung cancer who are diagnosed at an advanced stage. In addition, the molecular biological processes by which lung tumors develop have yet to be determined. Thus, there is an urgent need to clarify the possible mechanisms underlying the development of NSCLC, discover novel biomarkers for early screening, and develop therapeutic targets.

MicroRNAs (miRNAs) are endogenous small-noncoding RNAs of 20-25 nucleotides that can inhibit gene expression at either the mRNA or protein level $[3,4]$. miRNAs can promote or inhibit cell proliferation, differentiation, apoptosis, and necrosis by either inhibiting mRNA transcription or stalling translation [5-7]. Aberrant miRNA expression is associated with the occurrence of cancer in humans, such as colorectal cancer [8] and NSCLC [9]. Recently, miRNA (miR)-210, which is located on chromosome 11p15.5, was found to have multiple roles in various biological processes, such as angiogenesis and regulation of the immune system, by modulating cell proliferation, differentiation, degradation, and necrosis [10], and miR-210 was involved in the myocardial energy metabolism regulating the energy shift in cardiomyocytes during oxidative stress [11]. Deregulation of miR-210 may aberrantly activate oncogenes, deactivate tumor suppressor genes, inhibit DNA repair, and promote angiogenesis, ultimately accelerating the process of carcinogenesis, especially in a hypoxic environment [12]. miR-210 is aberrantly expressed in several cancers, such as malignant melanoma [13], pancreatic tumors [14], mammary cancer [15], and kidney carcinomas [16]. Several studies have reported the up-regulation of miR-210 expression using multiple microarrays [17-19]. In addition, a meta-analysis revealed the potential diagnostic capacity of miR-210 in NSCLC patients by detecting its expression level in blood and sputum [20].

In several previous studies, miR-210 expression was explored by analyzing fold changes in its levels, along with many other miRNAs, with the use of multiple microarrays. Because the specific expression level and clinical significance of miR-210 in NSCLC has not been fully elucidated, we decided to perform a comprehensive meta-analysis to reveal the specific expression level and clinical significance of miR-210 in NSCLC. In this study, we explored the expression level of miR-210 in NSCLC by mining data from 1673 samples on Gene Expression Omnibus (GEO) and 1090 samples on The Cancer Genome Atlas (TCGA), and then validated these findings via real-time quantitative PCR (RT-qPCR) analysis conducted on 125 paired clinical samples. To fully understand appreciate the clinical role of miR-210 in NSCLC, we also performed a meta-analysis by pooling the findings of previous studies: eligible GEO and TCGA datasets, RT-qPCR results, and qualified references. We then evaluated the diagnostic 


\section{Cellular Physiology Cell Physiol Biochem 2018;46:925-952 \begin{tabular}{l|l|l} 
DOI: 10.1159/000488823 & $\begin{array}{l}\text { ○ } 2018 \text { The Author(s). Published by S. Karger AG, Basel } \\
\text { www.karger.com/cpb }\end{array}$ \\
\hline
\end{tabular}}

He et al.: Clinical Value of MicroRNA-210 in NSCLC

and prognostic value of miR-210 in NSCLC, and performed bioinformatics analysis to illustrate the function of miR-210 in NSCLC by predicting its potential target genes and functional pathways.

\section{Materials and Methods}

Screening strategy for microarrays in the GEO datasets and references

The microarray profiles and datasets of NSCLC were acquired from GEO (http://www.ncbi.nlm.nih. gov/geo/). Public references in PubMed, Wiley Online Library, Web of Science, EMBASE, Chinese CNKI, Wan Fang, and Chong Qing VIP were screened for eligible studies that provided the expression level and prognostic value of miR-210 in NSCLC patients. The following search strategy was used: (miR-210 OR miR210 OR microRNA-210 OR microRNA210 OR miRNA-210 OR miRNA210) AND (lung OR pulmonary OR bronchi OR respiratory OR alveoli) AND (cancer OR carcinoma OR tumor OR neoplas* OR malignan* OR adenocarcinoma OR squamous).

\section{Inclusion criteria and data extraction}

The inclusion criteria were: (1) research participants with a diagnosis of NSCLC; (2) case control studies or studies including both a cancer group and control group (normal healthy participants or adjacent noncancerous tissue) with each containing at least 2 samples; (3) specific expression data of miR-210 in the case and control groups given as mean and standard deviation (SD); and (4) human research participants.

The required data were extracted independently from all eligible datasets and studies by two experienced investigators. Disagreements were settled by discussion with a third arbitral researcher. Detailed information was extracted from each eligible study: citation (ref.), unique PMID, year, country, region, sample type, data source, platform, miR-210 expression values, and sample size. For the selection of microarray expression data, the average value of the probes was regarded as the expression value of miR210 when more than 1 probe was used for detection.

\section{Data obtained from TCGA and preprocessing}

Level 3 expression data for miR-210 together with all corresponding accessible clinical information were retrieved for 999 NSCLCs and 91 normal control patients from TCGA. The corresponding paired tumor samples of 91 adjacent noncancerous tissue samples were selected from 999 NSCLC samples (45 lung squamous cell carcinoma samples and 46 lung adenocarcinoma samples) for paired-design analysis that would give a more precise outcome.

\section{Clinical NSCLC tissue samples and RT-qPCR analysis}

To validate the results of the online GEO and TCGA microarray databases, a total of 125 cancerous and corresponding adjacent normal lung tissues were collected from the Department of Pathology, First Affiliated Hospital of the Guangxi Medical University (Nanning, Guangxi, China) with the permission of the Ethics Committee of the First Affiliated Hospital of Guangxi Medical University.

Total RNA was extracted using a TRIzol reagent RNeasy FFPE Kit (QIAGEN, KJ Venlo, Netherlands). The $\mathrm{OD}_{260} / \mathrm{OD}_{280}$ ratio was obtained to measure the concentration and purity of extracted total RNA. RT-qPCR was conducted using a TaqMan MicroRNA Reverse Transcription Kit (Cat. No. 4366596; Tideradar Beijing Technology Co., Ltd., Beijing, China). Specific primers for miR-210 and the combination of miR-191 and miR-103 (internal control) were designed using Prime 3.0 and were provided by Invitrogen (Carlsbad, CA). A LightCycler 480 (Roche, Shanghai, China) was applied to analyze the PCR reactions. PCR efficiency values (E) for each gene were calculated using the formula $\mathrm{E}=10(-1 /$ slope $)$. The expression level of miR-210 was calculated using the $2-\Delta$ cq method.

Target gene prediction and bioinformatics analysis

For further analysis, differentially expressed genes (DE-genes) were determined from GEO microarrays (GSE33247 and GSE43622). The expression variation of specific genes was considered statistically significant when the absolute value of Log2 fold change was greater than 1.0 and the false discovery rate of the $\mathrm{P}$ value was less than 0.05 . Since the analysis of eligible literature and microarray datasets revealed 


\section{Cellular Physiology Cell Physiol Biochem 2018;46:925-952

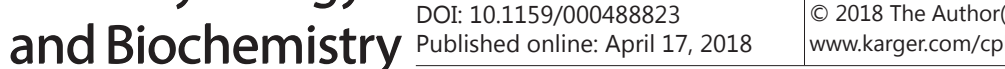

He et al.: Clinical Value of MicroRNA-210 in NSCLC

a trend for miR-210 to be overexpressed in NSCLC, miR-210 target genes were likely to be among the DEgenes with a comparatively lower expression level. Thus, down-regulated DE-genes in GSE33247 and GSE43622 were selected for further analysis.

Online prediction software (miRWalk, RNAhybrid, Microt4, PITA, miRDB, miRanda, mirbridge, miRNAMap, miRMap, Pictar2, RNA22, and TargetScan) and validated software (TarBase, miRTarBase, and miRecords) in miRWalk2.0 (http://zmf.umm.uni-heidelberg.de/apps/zmf/mirwalk2/) were respectively used to acquire predicted and validated target genes of miR-210. Then, we removed the repetitions and selected the genes that appeared in more than two of the above online prediction tools to overlap with the selected down-regulated DE-genes. The overlapping genes, which were regarded as potential targets of miR-210, were aggregated and annotated through biological process, cellular component, and molecular function in gene ontology (GO) enrichment analysis and Kyoto Encyclopedia of Genes and Genomes (KEGG) pathway analysis. Both GO and KEGG analysis in The Database for Annotation, Visualization, and Integrated Discovery 6.7(DAVID 6.7; https://david.ncifcrf.gov/) were used. After that, we employed Microsoft Excel 2016 to draw pie charts of the most significant 10 GO terms and KEGG pathways. Cytoscape was used to visualize the functional annotation and signaling pathways. Finally, the hub genes were input to the Search Tool for the Retrieval of Interacting Genes/Proteins (STRING; http://www.string-db.org/) for the construction of the protein-protein interaction relationship network. We also analyzed the expression levels of the final potential target genes in GEPIA (http://gepia.cancer-pku.cn), and the protein expression levels of 6 genes were assessed using the Human Protein Atlas (HPA; https://www.proteinatlas.org/). Corresponding scatter point plots of the target genes were constructed. Disease ontology analysis was conducted by using the ClusterProfiler package of the $\mathrm{R}$ language. $\mathrm{Q}$ and $\mathrm{P}$ values less than 0.05 were considered to indicate statistical significance. Moreover, further alterations in the levels of genes by miR-210 across NSCLC samples were examined using cBioPortal (http://cbioportal.org).

\section{Statistical analysis}

Means and SDs were estimated using SPSS 22.0. An independent-sample t-test was applied for random design studies, while a paired-sample t-test was used for the paired-design studies. Kaplan-Meier curve analysis was conducted for survival analysis, and multivariate Cox regression analysis was performed to evaluate the connection between the miR-210 expression state and prognostic outcome of NSCLC patients.

Overall standard mean deviation (SMD) was used as an overall effect size to assess the expression level of miR-210 in NSCLC. Q and I ${ }^{2}$ values were estimated to evaluate inter-study heterogeneity. Significant heterogeneity was defined when $\mathrm{P}<0.1$ or $\mathrm{I}^{2}>50 \%[21,22]$. Consequently, a random effects model was selected; otherwise, a fixed effects model was applied $[23,24]$. In addition, if significant heterogeneity was observed, subgroup analysis was performed to explore the possible sources of heterogeneity. To evaluate the stability of the overall estimates, sensitivity analysis was conducted by omitting one study at a time [25]. Furthermore, the existence of publication bias was estimated by generating a funnel plot and Egger's and Begg's test [26].

A bivariate model was used to combine the summary diagnostic values of the sensitivity and specificity of miR-210 expression for NSCLC [26], and a SROC curve was also constructed. The Midas package [27] was installed and applied in STATA 14.0 for analysis [28]. In addition, hazard ratios (HRs) along with 95\% confidence intervals (CIs) and other information from the published references were retrieved directly or extracted from the given Kaplan-Meier curve using Engauge 4.1. Then, the combined HR was generated in STATA 14.0 to evaluate the prognostic value of miR-210 in NSCLC.

All analyses were conducted by using SPSS 22.0 and STATA 14.0 .

\section{Results}

\section{Acquisition of all eligible data}

The raw expression data for miR-210 were acquired from GEO and TCGA datasets and we also searched for relevant published research papers. In addition, RT-qPCR was performed on 125 paired cancer and adjacent noncancerous tissue samples collected from NSCLC patients to validate the results obtained from the GEO and TCGA datasets. The expression level of miR-210 in NSCLC was estimated by SMD, which was obtained by merging all of 
Fig. 1. Summary of study structure and flow chart of GEO datasets and reference screening.

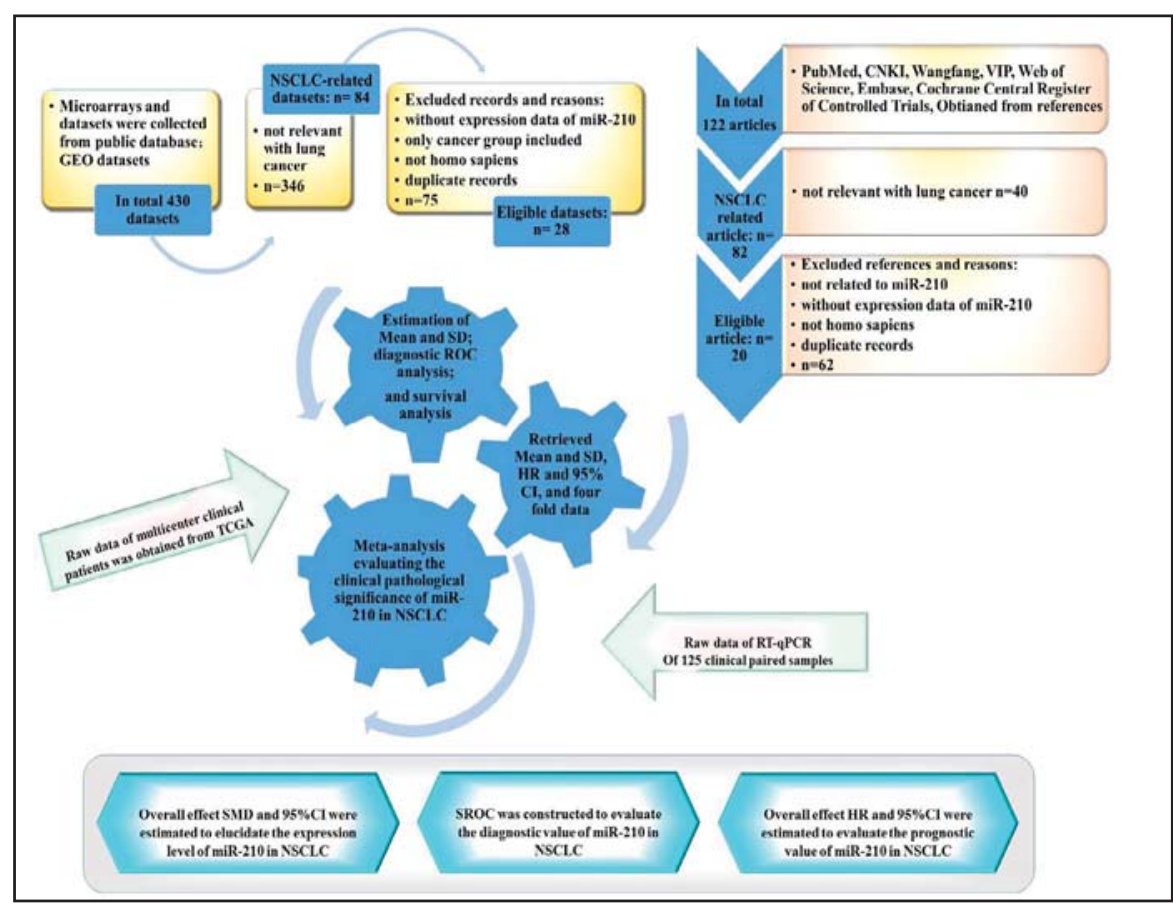

the accessible data derived from the above sources. To evaluate the capability of miR-210 for the diagnosis and prognosis of NSCLC, a receiver operating characteristic (ROC) curve and prognostic forest plots were constructed, respectively. The details of the dataset and reference screening processes and the overall design of the subsequent analyses are shown in Fig. 1.

In total, 28 eligible records and references were included in the analysis: GEO datasets $(n=24)$, TCGA $(n=1)$, in-house RT-qPCR $(n=1)$, and qualified references $(n=2[29,30])$. Their characteristics are summarized in Table 1. Overall, the 28 enrolled studies included 2551 NSCLC samples and 970 control samples with sample type being mainly dissected solid tissue ( 17 tissue, 5 blood, 3 plasma, and 3 serum) and the enrolled subjects were mainly from "Euramerica" (9 USA, 4 Germany, 1 Finland, 1 Netherlands, 1 Norway, and 1 Switzerland) and Asia (6 China and 4 Japan). In addition, 125 paired clinical cases of cancerous and paracancerous NSCLC tissues were collected from the First Affiliated Hospital of Guangxi Medical University with the approval of the hospital ethics committee and consent of the patients.

\section{Data processing}

Since raw expression data was acquired from GEO and TCGA databases, means and SDs were calculated to estimate the expression state of miR-210 in NSCLC by using SPSS 22.0. An independent-sample $t$ test was applied for random design studies, while a paired-samples $t$ test was used for the paired design studies. The results for these analyses are shown in Table 1 and intuitive scatter point plots are shown in Figs. 2-4.

As shown in Fig. 2, solid NSCLC tissues exhibited a consistently higher expression level of miR-210 than normal tissue in most GEO datasets. The analysis of 91 TCGA paired NSCLC samples and our own RT-qPCR results of 125 clinical paired NSCLC tissue samples validated this finding (Fig. 3). For the TCGA paired samples, the mean \pm SD of tumor and adjacent normal tissues were $11.69 \pm 1.84$ versus $7.42 \pm 1.48$, respectively $(\mathrm{P}<0.001)$, while RTqPCR analysis of 125 clinical paired tissues gave values of $6.24 \pm 3.50$ versus $3.51 \pm 2.76$, respectively $(\mathrm{P}<0.001)$. These findings indicate that miR-210 expression was considerably higher in NSCLC tissue than in adjacent normal tissue.

The expression of miR-210 in easily obtained body fluids (i.e., blood, plasma, and serum) is shown in Fig. 4, while its expression in tissue is shown in Fig. 2. The expression of miR-210 

Cellular Physiology Cell Physiol Biochem 2018;46:925-952

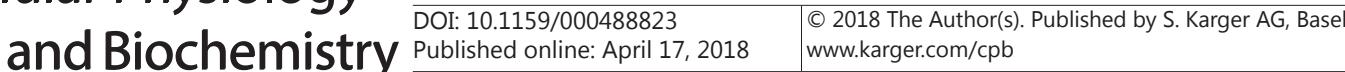 He et al.: Clinical Value of MicroRNA-210 in NSCLC

Table 1. Details of the datasets used in the present meta-analysis of NSCLC: eligible GEO datasets, results of RT-qPCR and TCGA analyses, and qualified references. P $<0.05$ was considered as significant. N0, N1: number of enrolled samples in the normal control group and experimental group, respectively. Ref NO.: The sequential reference numbers of citations. Citations of microarray datasets are displayed in the end of References list, and there are no citations available for the following 4 datasets: GSE19945 [101], GSE74190 [108], GSE77380 [109], GSE93300 [119], thus website address was affiliated

\begin{tabular}{|c|c|c|c|c|c|c|c|c|c|c|}
\hline Study ID & First author & Year & Ref NO. & Country & Nation & Sample type & Control N0. & Experiment N1. & T value & $P$ \\
\hline GSE14936 & Seike M & 2009 & [98] & USA & Euramerican & tissue & 26 & 26 & -2.445 & 0.018 \\
\hline GSE15008 & $\operatorname{Tan} X$ & 2010 & [99] & China & Asian & tissue & 112 & 112 & -11.960 & 0.000 \\
\hline GSE16025 & Raponi M & 2009 & [100] & USA & Euramerican & tissue & 10 & 61 & -6.518 & 0.000 \\
\hline GSE19945 & Ohba T & 2015 & [101] & Japan & Asian & tissue & 8 & 20 & -6.024 & 0.000 \\
\hline GSE25508 & Nymark P & 2011 & [102] & Finland & Euramerican & tissue & 26 & 26 & -6.468 & 0.000 \\
\hline GSE47525 & van Jaarsveld MT & 2013 & [103] & Netherlands & Euramerican & tissue & 14 & 18 & -1.809 & 0.080 \\
\hline GSE48414 & Bjaanaes MM & 2014 & [104] & Norway & Euramerican & tissue & 20 & 154 & -12.519 & 0.000 \\
\hline GSE51853 & Arima C & 2014 & [105] & Japan & Asian & tissue & 5 & 124 & -4.750 & 0.000 \\
\hline GSE63805 & Robles AI & 2015 & [106] & USA & Euramerican & tissue & 30 & 30 & -4.325 & 0.000 \\
\hline GSE72526 & Gasparini P & 2015 & [107] & Switzerland & Euramerican & tissue & 18 & 52 & -2.785 & 0.008 \\
\hline GSE74190 & $\operatorname{Jin} Y$ & 2015 & [108] & China & Asian & tissue & 38 & 38 & -8.090 & 0.000 \\
\hline GSE77380 & Yoshimoto $\mathrm{T}$ & 2016 & [109] & Japan & Asian & tissue & 12 & 12 & -3.423 & 0.003 \\
\hline GSE2564 & $\mathrm{Lu} \mathrm{J}$ & 2005 & [110] & USA & Euramerican & tissue & 4 & 14 & 2.078 & 0.054 \\
\hline GSE29248 & Ma L & 2012 & [111] & China & Asian & tissue & 6 & 6 & -1.700 & 0.151 \\
\hline GSE56036 & Fujita $Y$ & 2017 & [112] & Japan & Asian & tissue & 29 & 29 & -9.600 & 0.000 \\
\hline TCGA & NR & NR & NR & NR & NR & tissue & 91 & 999 & -28.679 & 0.000 \\
\hline TCGA & NR & NR & NR & NR & NR & tissue & 91 & 91 & -24.171 & 0.000 \\
\hline PCR & NR & $\mathrm{NR}$ & NR & China & Asian & tissue & 125 & 125 & -6.55 & 0.000 \\
\hline GSE17681 & Keller A & 2009 & [113] & Germany & Euramerican & blood & 10 & 17 & -0.985 & 0.335 \\
\hline GSE27486 & Patnaik SK & 2011 & [114] & USA & Euramerican & blood & 23 & 22 & -0.684 & 0.001 \\
\hline GSE31568 & Keller A & 2011 & [115] & Germany & Euramerican & blood & 70 & 32 & -1.620 & 0.109 \\
\hline GSE40738 & Patnaik SK & 2012 & [116] & USA & Euramerican & blood & 56 & 81 & 0.113 & 0.181 \\
\hline GSE61741 & Keller A & 2014 & [117] & Germany & Euramerican & blood & 94 & 72 & -1.210 & 0.228 \\
\hline GSE68951 & Leidinger $\mathrm{P}$ & 2015 & [118] & Germany & Euramerican & plasma & 12 & 26 & 1.774 & 0.085 \\
\hline GSE93300 & Liu X & 2017 & [119] & USA & Euramerican & plasma & 4 & 9 & 0.945 & 0.365 \\
\hline PMID:27499953 & Wang $\mathrm{X}$ & 2016 & [29] & China & Asian & plasma & 59 & 59 & -3.669 & 0.001 \\
\hline GSE16512 & Lodes MJ & 2009 & [120] & USA & Euramerican & serum & 14 & 3 & -2.690 & 0.017 \\
\hline GSE46729 & Godrey A & 2014 & [121] & USA & Euramerican & serum & 24 & 24 & -2.039 & 0.048 \\
\hline PMID:24065453 & Li ZH & 2014 & [30] & China & Asian & serum & 30 & 60 & NR & $<0.005$ \\
\hline
\end{tabular}

in blood, plasma, and serum of NSCLC patients varied, with 1 dataset exhibiting significantly low miR-210 expression in blood, 2 exhibiting significantly low miR-210 expression in blood, and the remaining 6 exhibiting no conspicuous difference. It is unfortunate that TCGA microarray analysis was conducted using only solid tissue from NSCLC patients because the corresponding expression data of miR-210 in blood and blood-component samples are lacking. Further validation via RT-qPCR was not performed due to the lack of easily obtained samples from clinical patients. Therefore, further study is needed to draw a conclusion on the expression level of miR-210 in easily obtained body fluids.

\section{Clinical significance of miR-210 in NSCLC}

Because the expression of miR-210 was varied in easily obtained body fluids and tissues in the GEO datasets, a meta-analysis was used to assess all of the data from the GEO datasets, the results from TCGA, RT-qPCR, and eligible publications to give an overall conclusion. The results are given in Table 2 and shown visually in Fig. 5A-5D. A forest plot merging all of the qualified data indicated that the expression level of miR-210 in NSCLC samples was 


\section{Cellular Physiology \\ Cell Physiol Biochem 2018;46:925-952 and Biochemistry

comparatively higher than in normal control samples (overall pooled SMD = 0.963, 95\% CI: 0.536-1.389, $\mathrm{P}<0.001)$ and significant heterogeneity was detected $\left(\mathrm{I}^{2}=95 \%\right)$. Therefore, a random model was applied, and exploring the source of the high heterogeneity became an imperative process for the present meta-analysis.

To investigate the potential source of heterogeneity, subgroup analysis was performed. As shown in Fig. 5B and 5C, we first conducted subgroup analysis stratified according to sample type. There was a dramatic drop of heterogeneity in the easily obtained body fluid groups-blood $\left(\mathrm{I}^{2}=74.00 \%\right)$, plasma $\left(\mathrm{I}^{2}=81.80 \%\right)$, and serum $\left(\mathrm{I}^{2}=60.10 \%\right)-$ and a small drop in the tissue-only group $\left(\mathrm{I}^{2}=93.90 \%\right)$. A significant difference was seen in the serum-only subgroup (SMD = 1.091, 95\% CI: 0.447-1.735, P $=0.001$ ) and tissue-only subgroup $(\mathrm{SMD}=1.425,95 \%$ CI: $0.915-1.9350, \mathrm{P}<0.001$ ), but not in the blood-only or plasma-only meta-analysis $(\mathrm{P}>0.05)$. The results of nation-based subgroup analysis are shown in Fig. 5D. Both the Euramerica-only group (SMD = $0.470,95 \%$ CI: $0.080-0.860, \mathrm{P}=0.018$ ) and Asian-only group $(\mathrm{SMD}=1.522,95 \% \mathrm{CI}$ : 1.33-1.911, $\mathrm{P}<0.001$ ) showed significant outcomes, and there was a clear drop in heterogeneity in each group $\left(\mathrm{I}^{2}=86.90 \%\right.$ and $81.80 \%$, respectively). These findings indicate that differences caused by sample
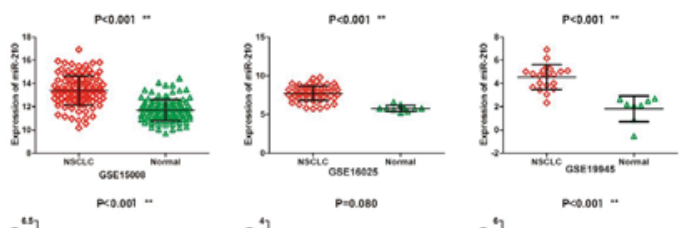

Pco.001 -
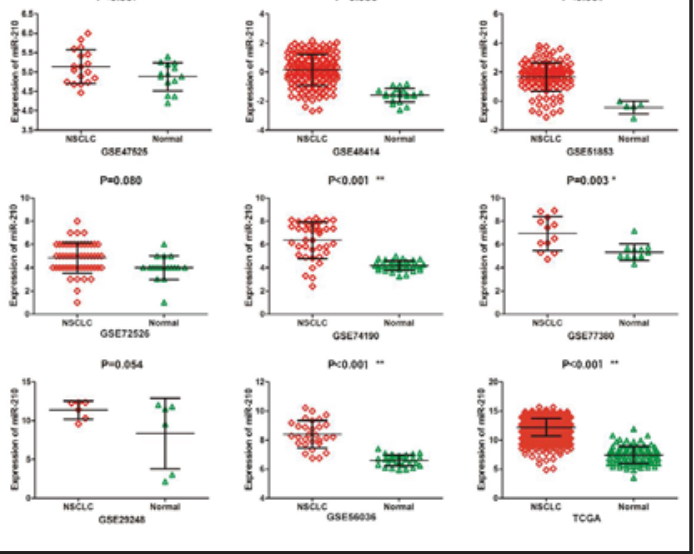

Fig. 2. Scatter point plots exhibiting miR-210 expression in tissue.

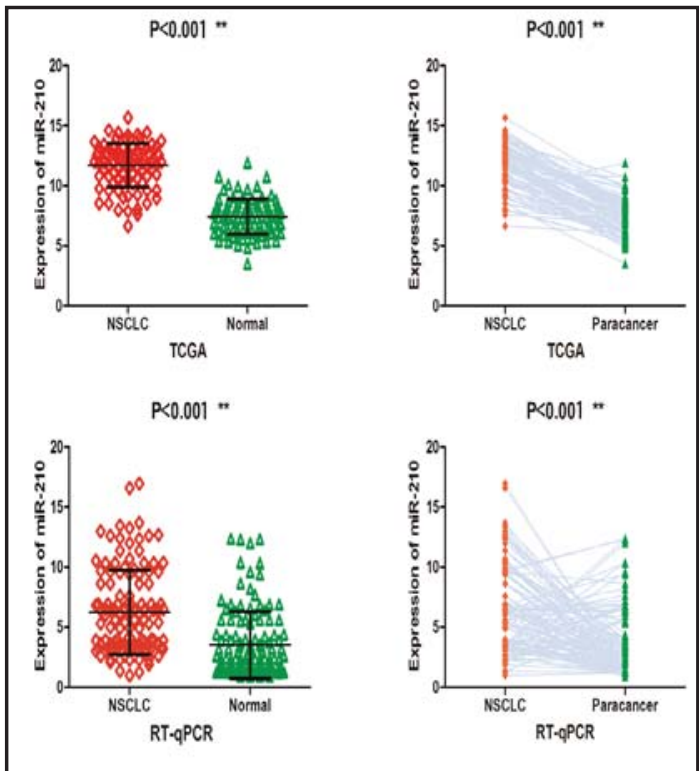

Fig. 3. TCGA and RT-qPCR analyses of paired samples. type and nation might, in part, be the sources of heterogeneity. Unfortunately, each platform used in the dataset was different; thus, sub-group analysis according to different detection approaches was not possible.

In the subsequent meta-analysis investigating miR-210 expression in NSCLC patients with different clinical pathologies (Table 2), miR-210 expression was comparatively higher in ever-smoking NSCLC cases than in non-smoking cases, while no significant differences were seen for the other clinical parameters (age, sex, lymph node metastasis, tumor, mode, metastasis stage, and tumor size; $\mathrm{P}>0.05$ ).

Sensitivity analysis indicated valid inter-study stability (Fig. 6A). A funnel plot (Fig. 6B) and Egger's and Begg's test (Table 2) indicated no significant publication bias $(\mathrm{P}>0.05)$. 


\section{Cellular Physiology Cell Physiol Biochem 2018;46:925-952 \begin{tabular}{l|l|l|l|}
\hline DOI: 10.1159/000488823 & ○ 2018 The Author(s). Published by S. Karger AG, Basel \\
\hline
\end{tabular} He et al: Clinical Value of MicroRNA-210 in NSCLC}

Diagnostic role of $\mathrm{miR}$ 210 in NSCLC

A diagnosis metaanalysis was performed to assess the diagnostic value of miR-210 to distinguish NSCLC patients from normal controls. A total of 40 records were included and 4741 patients were involved in this metaanalysis: 13 published articles [20, 29-40], 24 raw data GEO datasets and TCGA data, and our own RT-qPCR results for clinical patients. Among these records, details were provided on

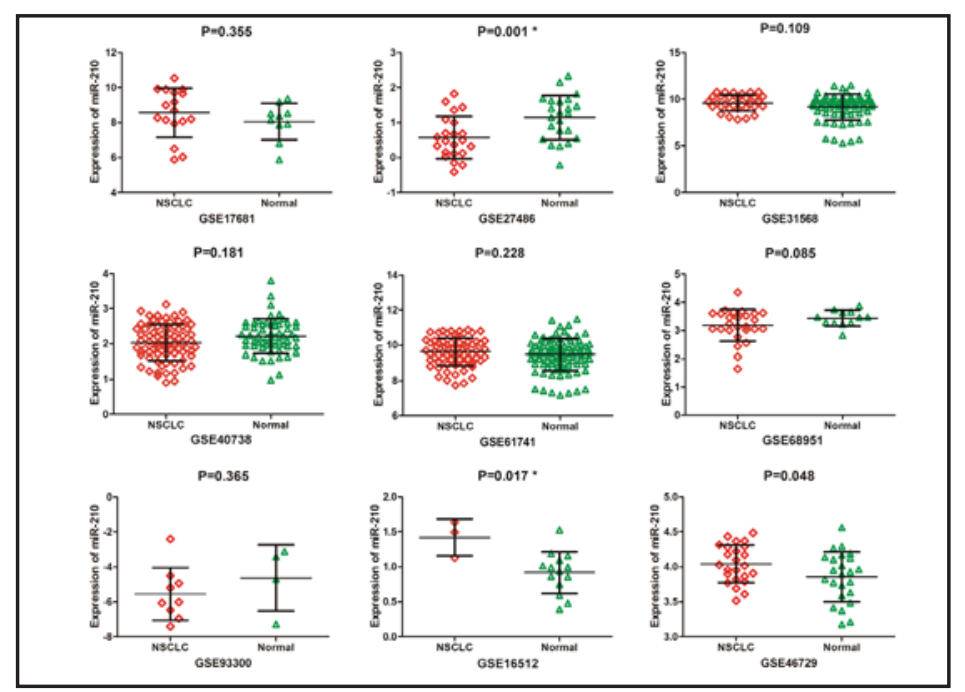

Fig. 4. Scatter point plots exhibiting miR-210 expression in blood, plasma, and serum.

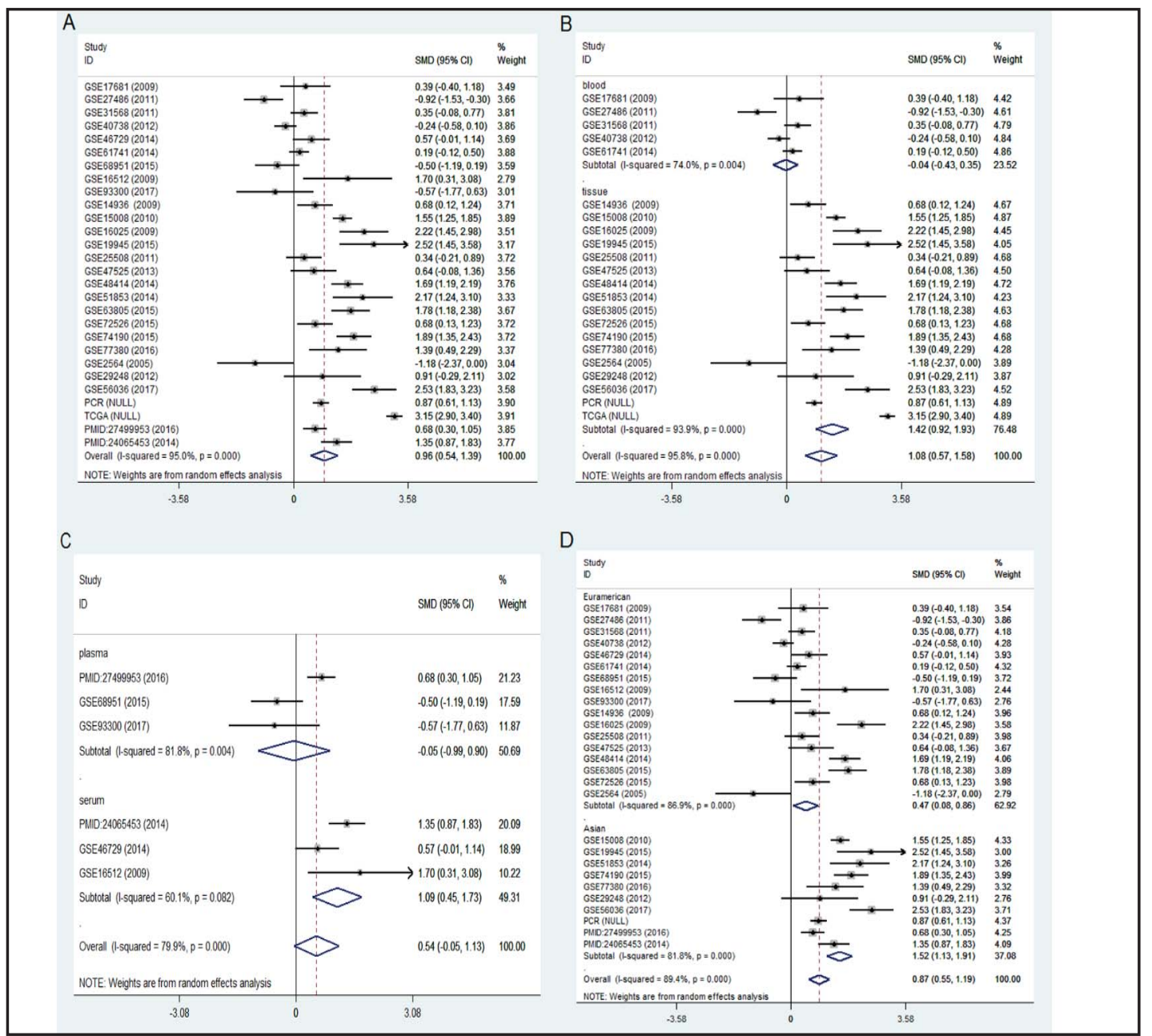

Fig. 5. A: NSCLC vs. normal, random-effects model. B: Subgroup analysis layered by sample type, blood and tissue, random-effects model. C: Subgroup analysis layered by sample type, plasma and serum, randomeffects model. D: Subgroup analysis, subgrouped into the Euramerican and Asian groups, random-effects model. 


\section{Cellular Physiology Cell Physiol Biochem 2018;46:925-952 \begin{tabular}{ll|l} 
and Biochemistry $10.1159 / 000488823$ & $\begin{array}{l}\text { C } 2018 \text { The Author(s). Published by S. Karger AG, Basel } \\
\text { www.karger.com/cpb }\end{array}$ \\
\hline
\end{tabular} \\ He et al.: Clinical Value of MicroRNA-210 in NSCLC}

Table 2. Expression level of miR-210 and clinical assessment: forest plots and publication bias analysis. Random: random-effects model; fixed: fixed-effects model; SMD: standard mean deviation; 95\% CI: 95\% confidence interval; LL: lower limit; UL: upper limit; NSCLC: non-small cell lung cancer; LNM: lymph node metastasis; TNM: tumor, node, metastasis; Het $\mathrm{X}^{2}: \mathrm{X}^{2}$ of heterogeneity $\mathrm{Q}$ test; $\mathrm{P}_{\text {het }}$ : P-value of heterogeneity; Egger's $\mathrm{P}_{\text {bias }}$ Begg's $\mathrm{P}_{\text {bias }}$ : $\mathrm{P}$ value of Egger's test and Begg's test, respectively

\begin{tabular}{|c|c|c|c|c|c|c|c|c|c|c|c|c|}
\hline \multirow{2}{*}{ Clinical parameters } & \multirow{2}{*}{$\begin{array}{l}\text { Study } \\
\text { number }\end{array}$} & \multirow{2}{*}{$\begin{array}{l}\text { Samples } \\
\text { number }\end{array}$} & \multirow{2}{*}{$\begin{array}{l}\text { Analysis } \\
\text { model }\end{array}$} & \multicolumn{4}{|c|}{ Overall estimate } & \multicolumn{3}{|c|}{ Heterogeneity } & \multicolumn{2}{|c|}{ Metabias } \\
\hline & & & & SMD & $95 \% \mathrm{CI}(\mathrm{LL} \cdot \mathrm{UL})$ & 2 & p & Het $X^{2}$ & $12(\%)$ & $P_{\text {bet }}$ & Egger $P_{\text {thias }}$ & Begg $P_{\text {tius }}$ \\
\hline normal/NSCLC (overall) & 28 & 3221 & Random & 0.963 & $(0.536 \cdot 1.389)$ & 4.42 & 0.000 & 535.95 & $95.00 \%$ & 0.000 & 0.361 & 0.707 \\
\hline normal/NSCLC(blood only) & 5 & 477 & Random & -0.038 & $(-0.431 \cdot 0.355)$ & 0.19 & 0.849 & 15.37 & $74.00 \%$ & 0.004 & 0.725 & 0.806 \\
\hline normal/NSCLC(serum only) & 3 & 141 & Random & 1.091 & $(0.447 \cdot 1.735)$ & 3.32 & 0.001 & 5.01 & $60.10 \%$ & 0.082 & 0.866 & 1.000 \\
\hline normal/NSCLC (phasma only) & 3 & 183 & Random & .0 .047 & $(-0.991 \cdot 0.897)$ & 1.69 & 0.100 & 10.97 & $81.80 \%$ & 0.004 & 0.312 & 1.000 \\
\hline normal/NSCLC (tissue only) & 17 & 2420 & Random & 1.425 & $(0.915 \cdot 1.935)$ & 5.48 & 0.000 & 261.68 & $93.90 \%$ & 0.000 & 0.298 & 0.592 \\
\hline normal/NSCLC (Asian only) & 10 & 1009 & Random & 1.522 & $(1.133-1.911)$ & 7.67 & 0.000 & 49.40 & $81.80 \%$ & 0.000 & 0.098 & 0.474 \\
\hline normal/NSCLC (Euramerican only) & 17 & 1122 & Random & 0.470 & $(0.080 \cdot 0.860)$ & 2.36 & 0.018 & 122.60 & $86.90 \%$ & 0.000 & 0.548 & 0.733 \\
\hline age $<60$ vs. $>60$ & 9 & 1374 & Random & 0.050 & $(-0.213-0.314)$ & 0.37 & 0.709 & 19.68 & $59.30 \%$ & 0.012 & 0.251 & 0.426 \\
\hline Female vs. Make & 11 & 1457 & Random & 0.166 & $(-0.061 \cdot 0.393)$ & 1.43 & 0.152 & 21.24 & $52.90 \%$ & 0.020 & 0.473 & 0.755 \\
\hline Non-LNM vs. LNM & 3 & 1122 & Random & 0.101 & $(-0.337 \cdot 0.540)$ & 0.45 & 0.651 & 11.35 & $82.40 \%$ & 0.003 & 0.877 & 1.000 \\
\hline Smoking & 4 & 1033 & fixed & 0.274 & $(0.136-0.413)$ & 3.88 & 0.000 & 1.97 & $0.00 \%$ & 0.579 & 0.464 & 0.734 \\
\hline TNM stage I vs. II & 3 & 840 & fixed & 0.049 & $(-0.095 \cdot 0.193)$ & 0.67 & 0.502 & 3.62 & $44.80 \%$ & 0.163 & 0.486 & 1.000 \\
\hline TNM stage I/II vs. III/IV & 4 & 1160 & Random & 0.190 & $(\cdot 0.143 \cdot 0.523)$ & 1.12 & 0.246 & 7.68 & $60.90 \%$ & 0.053 & 0.272 & 0.734 \\
\hline Tumor size $<3 \mathrm{~cm}$ vs. $\geq 3 \mathrm{~cm}$ & 3 & 225 & fixed & 0.299 & $(0.018-0.579)$ & 2.09 & 0.037 & 0.60 & $0.00 \%$ & 0.742 & 0.608 & 1.000 \\
\hline
\end{tabular}

miR-210 expression for solid tissue $(n=17)$, blood $(n=5)$, plasma $(n=6)$, serum $(n=6)$, and sputum $(\mathrm{n}=6)$, as shown in Table 3.

An ROC curve of every dataset was generated and the 4-fold table data were also estimated. The ROC curves of datasets with easily obtained sample types (Fig. 7) show varied diagnostic value. Overall, the ROC curve of datasets with dissected solid tissue showed relatively high diagnostic value (Fig. 8). The ROC curve of 125 clinical paired NSCLC tissues and 91 TCGA paired NSCLC samples confirmed the positive results of the GEO datasets with dissected solid tissue (Fig. 9). Because there was some controversy in the diagnostic value of miR-210, SROC plots containing all of the data from the GEO datasets and the results of TCGA and RT-qPCR analyses, as well as eligible publications, were constructed to draw a credible conclusion.

The overall combined area under the curve (AUC) was 0.83 (95\% CI: 0.79-0.86), and sensitivity and specificity were 0.72 and 0.80 , respectively (Table 4 and Fig. 10). To consider the potential application of miR-210 for clinical diagnosis, we excluded records providing the expression level of miR-210 in solid tissue and merged the data that were obtained from the easily obtained body fluids. The combined AUC of the tissue-excluded data was 0.77 (95\% CI: 0.73-0.80), with sensitivity and specificity of 0.65 and 0.76 , respectively. However, significant heterogeneity was observed in the overall estimation for only the easily obtained body fluid estimation (tissue-excluded estimation) with large $Q$ and $I^{2}$ values. Thus, subgroup analysis was performed to investigate the potential sources of this heterogeneity. 


\section{Cellular Physiology \\ Cell Physiol Biochem 2018;46:925-952

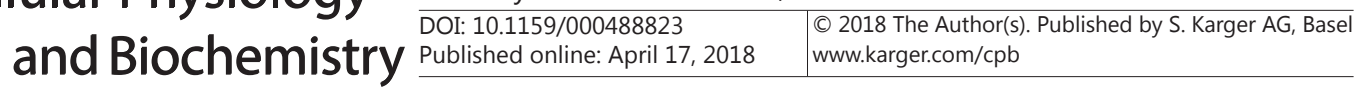 \\ He et al.: Clinical Value of MicroRNA-210 in NSCLC}

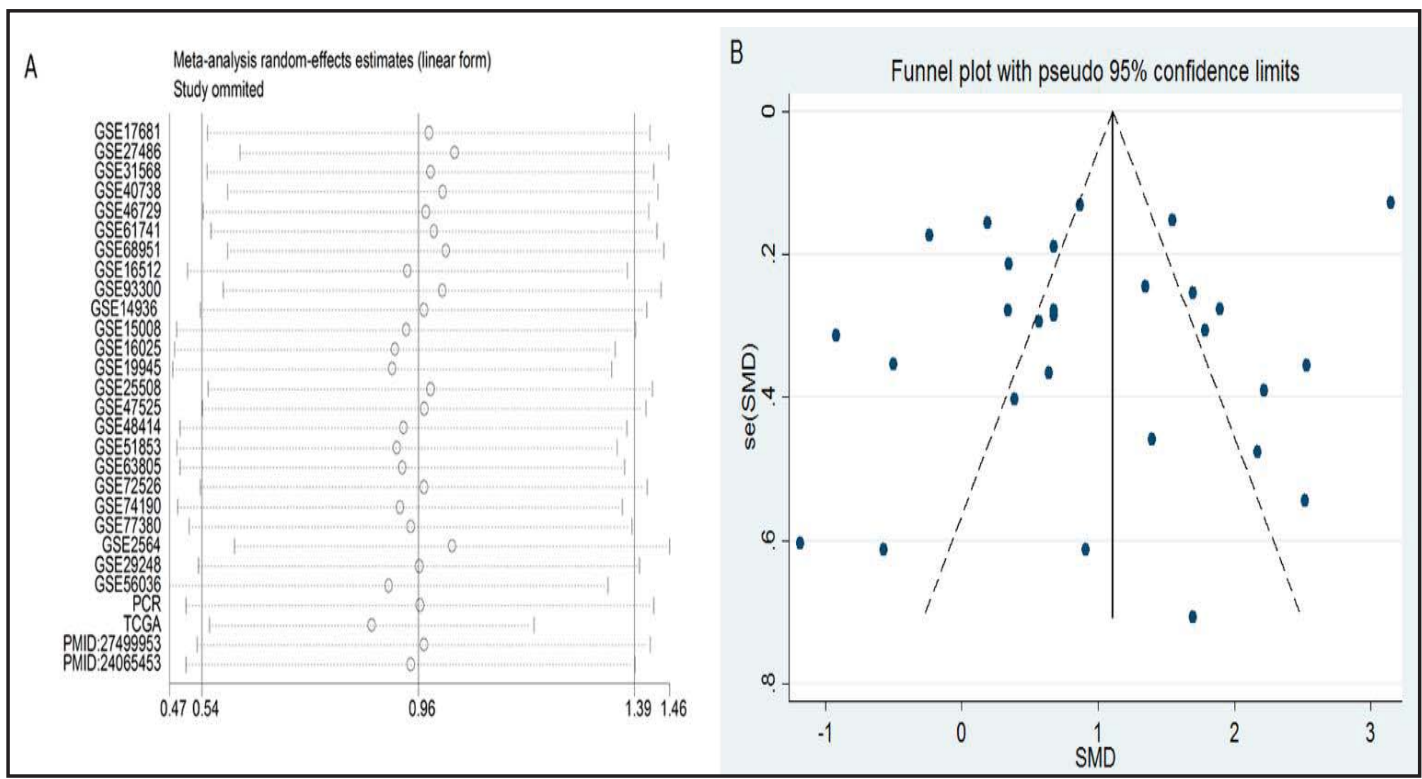

Fig. 6. A: Funnel plot. B: Visualized graph of influence analysis.

Subgroup analysis according to the sample type of the records revealed overall AUCs for blood, plasma, serum (Fig. 11A) and sputum (Fig. 11B) were $0.61,0.73,0.82$, and 0.81 , respectively. As shown in Table 4, the heterogeneity in the plasma and sputum groups declined dramatically with the $\mathrm{I}^{2}$ value being reduced to $0.00 \%$, while that in the blood and serum groups showed only a smaller drop with an $\mathrm{I}^{2}$ value of 98\%. Thus, the expression of miR-210 in sputum was relatively consistent $\left(\mathrm{I}^{2}=0.00 \%\right)$ and had high diagnostic capacity (0.81,

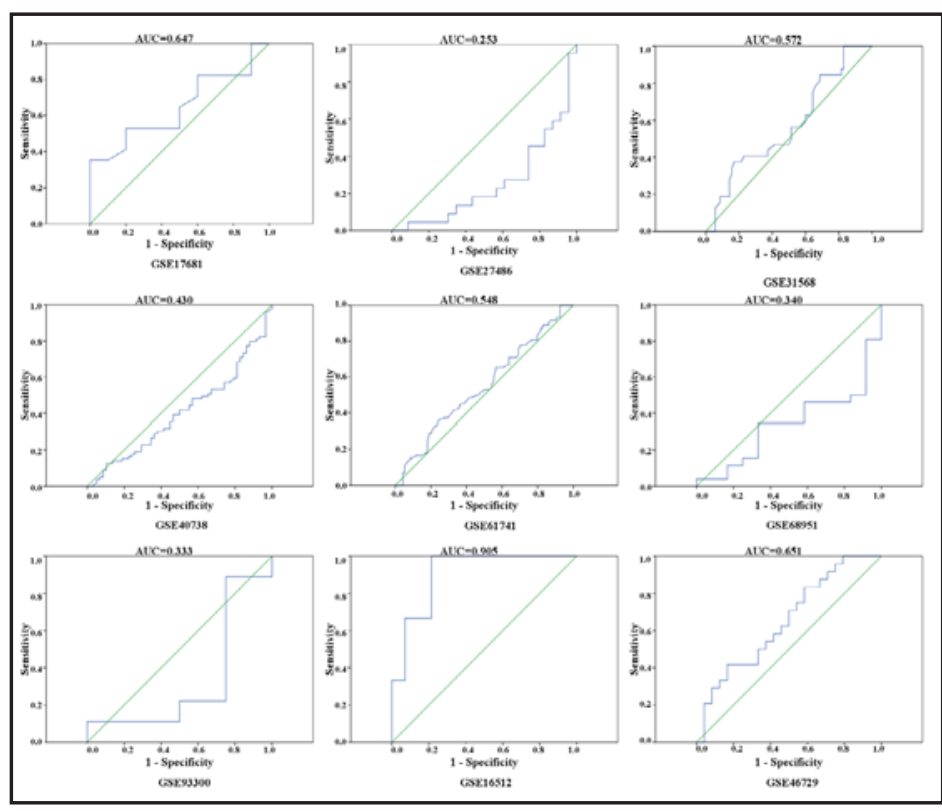

Fig. 7. ROC curves exhibiting the diagnostic value of miR-210 in blood, plasma, serum, and plasma. 95\% CI: 0.78-0.84).

Prognostic significance of miR-210 in NSCLC

Forest plots were generated to evaluate the prognostic role of miR-210 in NSCLC. There were a total of 2 GEO datasets and 4 public studies [35, 41-43], as well as our own RT-qPCR results with an overall number of 396 patients included in this meta-analysis (Table 5). A fixed model was selected for estimation as no significantly high heterogeneity was observed. All of the effects for overall survival (OS), disease-free survival (DFS), and progression-free survival (PFS) showed significant differences in survival outcome with HRs of 0.602 (OS, 95\% CI: 0.410-0.884), 0.360 (DFS, 95\% CI: 0.194-0.667), and 2.020 (PFS, 95\% CI: 1.366-2.988; Table 
6 and Fig. 12A-12C). This indicates that miR210 overexpression was associated with poor PFS in NSCLC, while it was negatively related to OS and DFS. Moreover, no instability was seen in the constructed influence plot (Fig. 13A), and no publication bias was detected in a funnel plot (Fig. 13B) or Begg's and Egger's test.

Bioinformatics analysis of miR-210 in NSCLC

After integrating the outcomes of the 12 online prediction software tools, there were 17,010 potential target genes. We selected 8645 genes that were identified in more than two prediction tools to overlap with the DE-genes (Fig. 14). Eventually, a total of 709 genes were considered as candidate target genes of miR-210. Bioinformatics analysis was then employed for these genes using DAVID 6.7.

Ten GO terms were

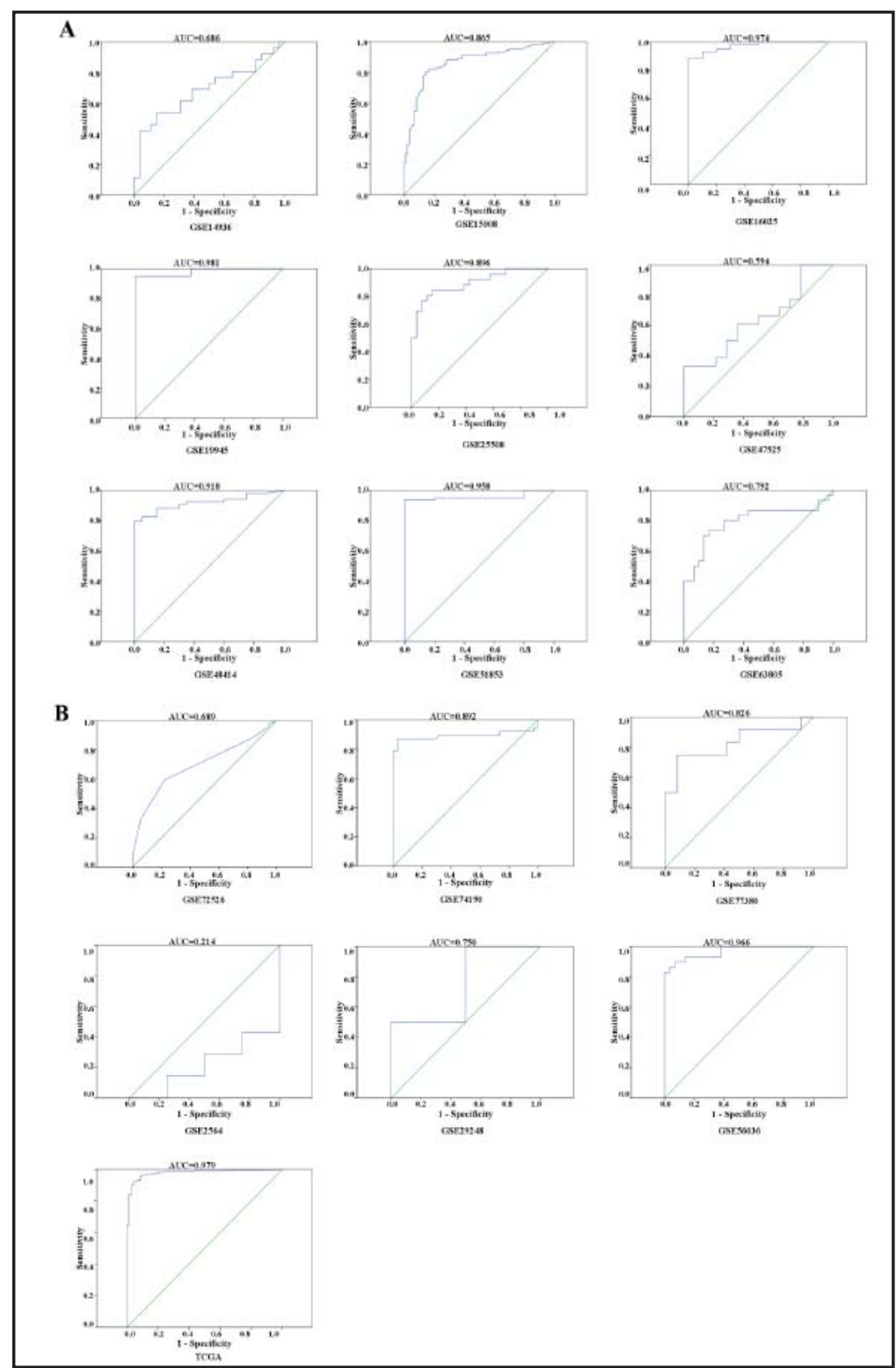

Fig. 8. A and B: ROC curves exhibiting the diagnostic value of miR-210 in tissue.
Fig. 9. ROC curves of TCGA and RT-qPCR paired-design studies.
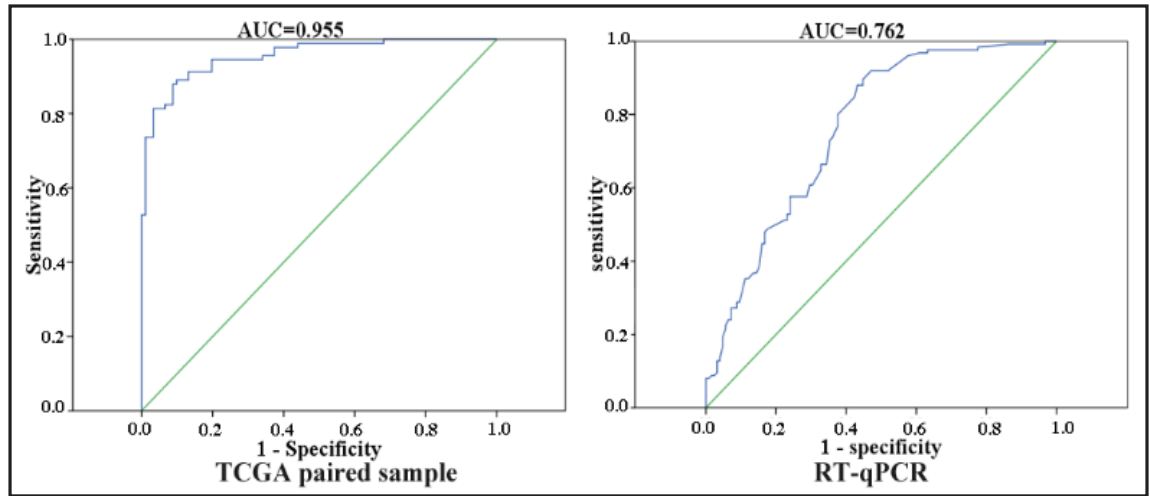

Cellular Physiology Cell Physiol Biochem 2018:46:925-952

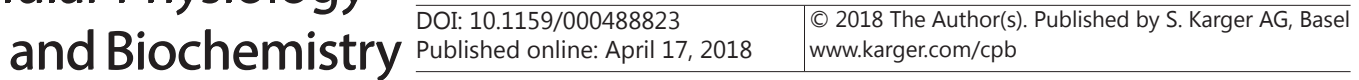 He et al:: Clinical Value of MicroRNA-210 in NSCLC

Table 3. ROC 4-fold table for all available data. N0, N1: number of enrolled samples in the normal control group and experimental group, respectively; AUC: area under the receiver operating characteristic curve; TP: true positive value; FN: false negative value; FP: false positive value; TN: true negative value; NR: information not reported. Ref NO.: The sequential reference numbers of citations. Citations of microarray datasets are displayed in the end of References list, and there are no citations available for the following 4 datasets: GSE19945 [101], GSE74190 [108], GSE77380 [109], GSE93300 [119], thus website address was affiliated. Study1 (Xia et al, [34]) and Study2 (Zhou et al, [35]) are the codes for two Chinese articles; the corresponding articles are displayed at the end of References section

\begin{tabular}{|c|c|c|c|c|c|c|c|c|c|c|c|c|c|c|c|c|}
\hline ID & Author & Year & $\begin{array}{l}\text { Ref } \\
\text { No. }\end{array}$ & Country & Nation & Sample type & No & $\mathrm{N} 1$ & AUCs & Thresholds & Sensitivity & Specificity & TP & FN & FP & $\mathrm{TN}$ \\
\hline GSE72526 & $\begin{array}{c}\text { Gasparini } \\
\text { P }\end{array}$ & 2015 & [107] & Switzerland & Euramerican & tissue & 18 & 52 & 0.698 & 4.500 & 0.596 & 0.788 & 31 & 21 & 4 & 14 \\
\hline GSE2564 & $\mathrm{LuJ}$ & 2005 & [110] & USA & Euramerican & tissue & 4 & 14 & 0.214 & 7.700 & 0.286 & 0.500 & 4 & 10 & 2 & 2 \\
\hline GSE77380 & $\begin{array}{c}\text { Yoshimoto } \\
\mathrm{T}\end{array}$ & 2016 & [109] & Japan & Asian & tissue & 12 & 12 & 0.826 & 5.936 & 0.750 & 0.917 & 9 & 3 & 1 & 11 \\
\hline GSE47525 & $\begin{array}{c}\text { van } \\
\text { Jaarsveld } \\
\text { MT }\end{array}$ & 2013 & [103] & Netherlands & Euramerican & tissue & 14 & 18 & 0.594 & 5.469 & 0.333 & 1.000 & 6 & 12 & 0 & 14 \\
\hline GSE19945 & Ohba T & 2015 & {$[101]$} & Japan & Asian & tissue & 8 & 20 & 0.981 & 2.872 & 0.950 & 1.000 & 19 & 1 & 0 & 8 \\
\hline GSE74190 & $\operatorname{Jin} Y$ & 2015 & [108] & China & Asian & tissue & 38 & 38 & 0.892 & 4.807 & 0.868 & 0.026 & 33 & 5 & 37 & 1 \\
\hline GSE48414 & $\begin{array}{c}\text { Bjaanaes } \\
\text { Mм }\end{array}$ & 2014 & [104] & Norway & Euramerican & tissue & 20 & 154 & 0.918 & -0.820 & 0.799 & 1.000 & 123 & 31 & 0 & 20 \\
\hline GSE16025 & Raponi M & 2009 & [100] & USA & Euramerican & tissue & 10 & 61 & 0.974 & 6.590 & 0.885 & 1.000 & 54 & 7 & 0 & 10 \\
\hline GSE51853 & Arima C & 2014 & {$[105]$} & Japan & Asian & tissue & 5 & 124 & 0.958 & -0.004 & 0.935 & 1.000 & 116 & 8 & 0 & 5 \\
\hline GSE63805 & Robles AI & 2015 & {$[106]$} & USA & Euramerican & tissue & 30 & 30 & 0.792 & 4.526 & 0.733 & 0.833 & 22 & 8 & 5 & 25 \\
\hline GSE15008 & $\operatorname{Tan} X$ & 2010 & [99] & China & Asian & tissue & 112 & 112 & 0.865 & 12.423 & 0.821 & 0.839 & 92 & 20 & 18 & 94 \\
\hline GSE14936 & Seike M & 2009 & [98] & USA & Euramerican & tissue & 26 & 26 & 0.686 & 9.504 & 0.538 & 0.846 & 14 & 12 & 4 & 22 \\
\hline GSE29248 & $\mathrm{MaL}$ & 2012 & [111] & China & Asian & tissue & 6 & 6 & 0.750 & 0.578 & 1.000 & 0.500 & 6 & 0 & 3 & 3 \\
\hline GSE56036 & Fujita $Y$ & 2017 & [112] & Japan & Asian & tissue & 29 & 29 & 0.966 & 7.233 & 0.862 & 0.966 & 25 & 4 & 1 & 28 \\
\hline GSE25508 & Nymark P & 2011 & [102] & Finland & Euramerican & tissue & 26 & 26 & 0.891 & 7.670 & 0.808 & 0.885 & 21 & 5 & 3 & 23 \\
\hline TCGA & NR & NR & NR & NR & NR & tissue & 91 & 999 & 0.978 & 9.938 & 0.919 & 0.956 & 918 & 81 & 4 & 87 \\
\hline PCR & NR & NR & NR & China & Asian & tissue & 125 & 125 & 0.762 & 2.500 & 0.920 & 0.528 & 115 & 10 & 59 & 66 \\
\hline GSE61741 & Keller A & 2014 & [117] & Germany & Euramerican & blood & 94 & 72 & 0.548 & 9.988 & 0.361 & 0.755 & 26 & 46 & 23 & 71 \\
\hline GSE40738 & Patnaik SK & 2012 & [116] & USA & Euramerican & blood & 56 & 81 & 0.430 & 2.639 & 0.148 & 0.911 & 12 & 69 & 5 & 51 \\
\hline GSE31568 & Keller A & 2011 & [115] & Germany & Euramerican & blood & 70 & 32 & 0.572 & 10.130 & 0.375 & 0.839 & 12 & 20 & 11 & 59 \\
\hline GSE27486 & Patnaik SK & 2011 & [114] & USA & Euramerican & blood & 23 & 22 & 0.253 & -0.215 & 0.955 & 0.043 & 21 & 1 & 22 & 1 \\
\hline GSE17681 & Keller A & 2009 & [113] & Germany & Euramerican & blood & 10 & 17 & 0.647 & 8.610 & 0.529 & 0.800 & 9 & 8 & 2 & 8 \\
\hline PMID:24053570 & $\begin{array}{c}\text { Anjuman } \\
\mathrm{N}\end{array}$ & 2013 & [31] & USA & Euramerican & plasma & 42 & 39 & 0.767 & NR & 0.692 & 0.762 & 27 & 12 & 10 & 32 \\
\hline PMID:21116241 & Shen J & 2011 & [32] & USA & Euramerican & plasma & 29 & 58 & 0.746 & NR & 0.741 & 0.690 & 43 & 15 & 9 & 20 \\
\hline PMID:21864403 & Shen J & 2011 & [33] & USA & Euramerican & plasma & 33 & 32 & 0.691 & 2.001 & 0.563 & 0.727 & 18 & 14 & 9 & 24 \\
\hline PMID:27499953 & Wang $\mathrm{X}$ & 2016 & [29] & China & Asian & plasma & 59 & 59 & 0.751 & 3.341 & 0.746 & 0.746 & 44 & 15 & 15 & 44 \\
\hline GSE68951 & $\begin{array}{c}\text { Leidinger } \\
\quad P\end{array}$ & 2015 & [118] & Germany & Euramerican & plasma & 12 & 26 & 0.340 & 3.496 & 0.346 & 0.677 & 9 & 17 & 4 & 8 \\
\hline GSE93300 & Liu X & 2017 & [119] & USA & Euramerican & plasma & 4 & 9 & 0.333 & -7.113 & 0.889 & 0.250 & 8 & 1 & 3 & 1 \\
\hline Study1 & Xia XB & 2017 & [34] & China & Asian & serum & 46 & 58 & 0.824 & NR & 0.759 & 0.804 & 44 & 14 & 9 & 37 \\
\hline PMID:24065453 & LizH & 2014 & [30] & China & Asian & serum & 30 & 60 & 0.775 & 1.307 & 0.787 & 0.740 & 47 & 13 & 8 & 22 \\
\hline Study2 & Zhou JL & 2018 & [35] & China & Asian & serum & 40 & 48 & 0.845 & NR & 0.741 & 0.782 & 36 & 12 & 9 & 31 \\
\hline PMID:27093275 & Zhu WY & 2016 & [20] & China & Asian & serum & 104 & 112 & 0.616 & 0.107 & 0.339 & 1.000 & 38 & 74 & 0 & 104 \\
\hline GSE46729 & Godrey A & 2014 & [121] & USA & Euramerican & serum & 24 & 24 & 0.651 & 3.785 & 0.833 & 0.417 & 20 & 4 & 14 & 10 \\
\hline GSE16512 & Lodes MJ & 2009 & [120] & USA & Euramerican & serum & 14 & 3 & 0.905 & 1.110 & 1.000 & 0.786 & 3 & 0 & 3 & 11 \\
\hline PMID:24305007 & Shen J & 2014 & [36] & USA & Euramerican & sputum & 68 & 66 & 0.780 & NR & 0.658 & 0.738 & 43 & 23 & 18 & 50 \\
\hline PMID:24305007 & Shen J & 2014 & [36] & USA & Euramerican & sputum & 73 & 64 & 0.790 & NR & 0.626 & 0.718 & 40 & 24 & 21 & 52 \\
\hline PMID:20526284 & Xing $\mathrm{L}$ & 2010 & [37] & USA & Euramerican & sputum & 48 & 48 & 0.748 & 1.640 & 0.583 & 0.792 & 28 & 20 & 10 & 38 \\
\hline PMID:25593345 & Xing $\mathrm{L}$ & 2015 & [38] & USA & Euramerican & sputum & 62 & 60 & 0.853 & NR & 0.753 & 0.859 & 45 & 15 & 9 & 53 \\
\hline PMID:24281335 & Li N & 2014 & [39] & USA & Euramerican & sputum & 40 & 35 & 0.730 & NR & 0.571 & 0.900 & 20 & 15 & 4 & 36 \\
\hline PMID:27777637 & SuY & 2016 & [40] & China & Asian & sputum & 171 & 144 & 0.840 & $\mathrm{NR}$ & 0.766 & 0.812 & 110 & 34 & 32 & 139 \\
\hline
\end{tabular}




\section{Cellular Physiology \\ Cell Physiol Biochem 2018;46:925-952 \\ \begin{tabular}{l|l}
\hline DOI: $10.1159 / 000488823$ & C 2018 The Author(s). Published by S. Karger AG, Base
\end{tabular} and Biochemistry Published online: April 17, 2018 www.karger.com/cpb

identified in which the target genes were greatly enriched in biological process, cellular component, and molecular function (Fig. 15A-15C). Cell adhesion was the most significant GO term of biological process, while plasma membrane, integral component of plasma membrane, and proteinaceous extracellular matrix were largely enriched in cellular component. As for molecular function, Ras guanyl-nucleotide exchange factor activity and actin binding were the two most relevant GO terms. We also identified 10 significant pathways in KEGG (Fig. 15D), among which renin secretion, the cGMP-PKG signaling pathway, and cell adhesion molecules showed extraordinary significance. Additionally, we used Cytoscape to visualize the functional annotation and signaling pathways (Fig. 16A-16C). The proteinprotein interaction network, which was constructed using STRING, contained 80 hub genes (Fig. 17) and suggested that 6 target genes might be key

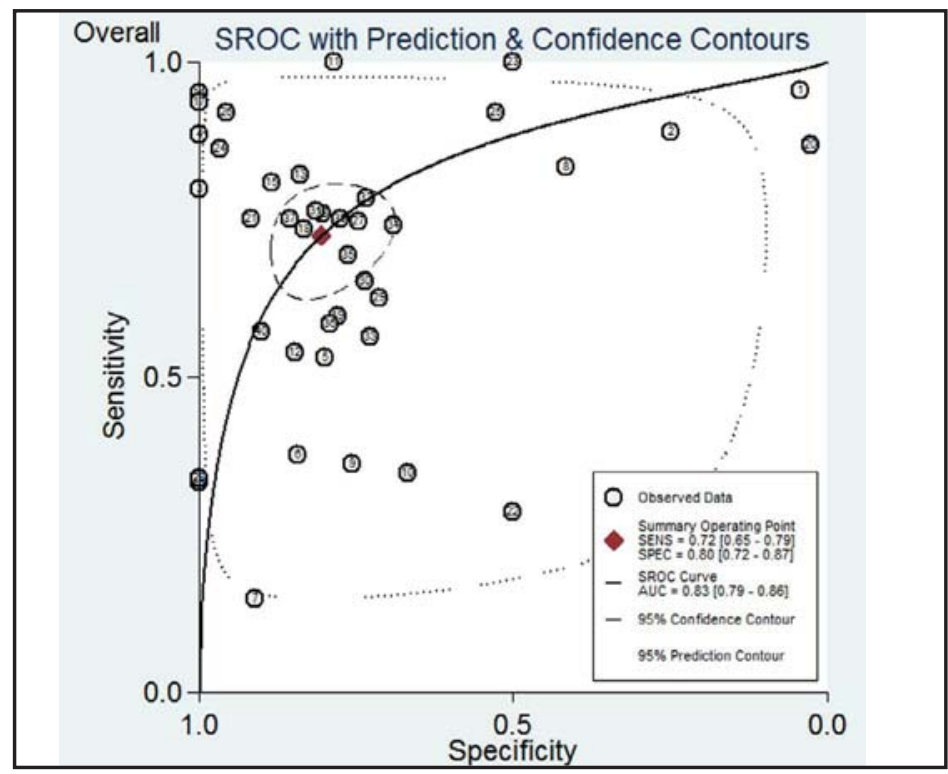

Fig. 10. Overall SROC graph evaluating the capacity of miR-210 to distinguish NSCLC patients from normal controls.

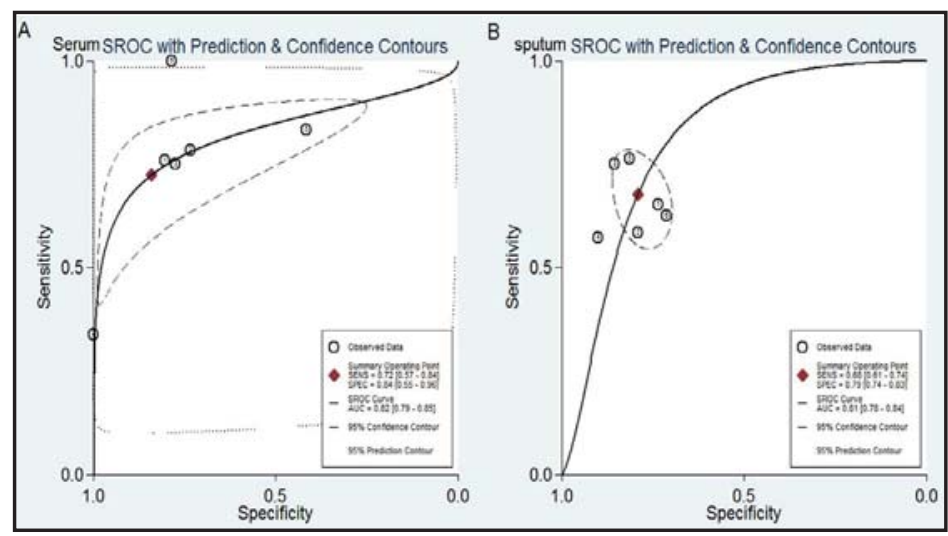

Fig. 11. SROC graph evaluating the capacity of miR-210 to distinguish NSCLC patients from normal controls. A: Serum-only samples. B: Sputum-only samples.

Table 4. ROC analysis of all available data. AUC: area under receiver operating characteristic curve; $95 \%$ CI: $95 \%$ confidence interval; LL: lower limit; UL: upper limit. Q: heterogeneity $\mathrm{Q}$ test; $\mathrm{P}_{\text {het }}$ : P value of heterogeneity

\begin{tabular}{|c|c|c|c|c|c|c|c|c|c|c|}
\hline \multirow{2}{*}{ Sample type } & \multirow{2}{*}{$\begin{array}{l}\text { Study } \\
\text { number }\end{array}$} & \multirow{2}{*}{$\begin{array}{l}\text { Enrolled } \\
\text { number }\end{array}$} & \multicolumn{4}{|c|}{ Overall estimate } & \multicolumn{3}{|c|}{ Heterogeneity } & \multirow{2}{*}{$\begin{array}{c}\text { Threshold } \\
\text { effect }\end{array}$} \\
\hline & & & AUC & 95\%CI(LL-UL) & sensitivity & specificity & Q & $\mathrm{I}^{2}(\%)$ & $P_{\text {het }}$ & \\
\hline Overall & 40 & 4741 & 0.83 & $(0.79-0.86)$ & 0.72 & 0.80 & 354.195 & $99.00 \%$ & 0.000 & $8.00 \%$ \\
\hline Tissue & 17 & 2420 & 0.90 & $(0.87-0.92)$ & 0.81 & 0.89 & 116.931 & $98.00 \%$ & 0.000 & $0.00 \%$ \\
\hline Tissue-excluded & 23 & 2321 & 0.77 & $(0.73-0.80)$ & 0.65 & 0.76 & 190.259 & $99.00 \%$ & 0.000 & $60.00 \%$ \\
\hline Blood & 5 & 477 & 0.61 & $(0.56-0.65)$ & 0.50 & 0.67 & 97.754 & $98.00 \%$ & 0.000 & $100.00 \%$ \\
\hline Plasma & 6 & 402 & 0.73 & $(0.69-0.76)$ & 0.66 & 0.72 & 3.163 & $37.00 \%$ & 0.103 & $100.00 \%$ \\
\hline Serum & 6 & 563 & 0.82 & $(0.79-0.85)$ & 0.72 & 0.84 & 92.465 & $98.00 \%$ & 0.000 & $100.00 \%$ \\
\hline Sputum & 6 & 879 & 0.81 & $(0.78-0.84)$ & 0.68 & 0.79 & 0.173 & $0.00 \%$ & 0.459 & $100.00 \%$ \\
\hline
\end{tabular}




\section{Cellular Physiology Cell Physiol Biochem 2018;46:925-952 \begin{tabular}{ll|l} 
and Biochemist 10.1159/000488823 & $\begin{array}{l}\text { @ 2018 The Author(s). Published by S. Karger AG, Basel } \\
\text { www.karger.com/cpb }\end{array}$ \\
\hline
\end{tabular} \\ He et al.: Clinical Value of MicroRNA-210 in NSCLC}

Table 5. Available studies with miR-210-related survival analysis. OS: overall survival; DFS: disease-free survival; PFS: progression-free survival; HR: hazard ratio; LL: lower limit of the $95 \%$ confidence interval; UL: upper limit of the 95\% confidence interval; LUSC: lung squamous cell carcinoma; NSCLC: non-small cell lung cancer; ADC: adenocarcinoma; LUAD: lung adenocarcinoma. Ref NO.: The sequential reference numbers of citations. Citations of microarray datasets are displayed in the end of References list, and there are no citations available for the following 4 datasets: GSE19945 [101], GSE74190 [108], GSE77380 [109], GSE93300 [119], thus website address was affiliated. Study2 (Zhou et al., [35]) and Study3 (Lu et al., [42]) are the codes for two Chinese articles; the corresponding articles are displayed at the end of References section

\begin{tabular}{|c|c|c|c|c|c|c|c|c|c|c|c|c|c|c|}
\hline Data source & Author & Year & $\begin{array}{l}\text { Ref } \\
\text { No. }\end{array}$ & Country & Nation & $\begin{array}{l}\text { Cancer } \\
\text { type }\end{array}$ & $\begin{array}{l}\text { Total } \\
\text { enroll }\end{array}$ & $\begin{array}{l}\text { Sample } \\
\text { type }\end{array}$ & $\begin{array}{l}\text { Analysis } \\
\text { method }\end{array}$ & Event type & HR & LL & & UL \\
\hline GSE16025 & Raponi M & 2009 & [100] & USA & Euramerica & LUSC & 61 & & tissue & $\begin{array}{c}\text { Multivariate } \\
\text { analysis }\end{array}$ & OS & 0.938 & 0.473 & 1.861 \\
\hline GSE63805 & Robles AI & 2015 & [106] & USA & Euramerica & NSCLC & 30 & & tissue & $\begin{array}{c}\text { Multivariate } \\
\text { analysis }\end{array}$ & OS & 0.367 & 0.127 & 1.063 \\
\hline PMID:25733977 & Osugi I & 2015 & [41] & Japan & Asian & $\mathrm{ADC}$ & 62 & & tissue & $\begin{array}{c}\text { Multivariate } \\
\text { analysis }\end{array}$ & OS & 0.36 & 0.13 & 1.03 \\
\hline Study3 & LuS & 2015 & [42] & China & Asian & $A D C$ & 62 & & tissue & $\begin{array}{c}\text { Multivariate } \\
\text { analysis }\end{array}$ & OS & 0.36 & 0.13 & 1.03 \\
\hline PCR & NR & NR & NR & China & Asian & NSCLC & 57 & & tissue & $\begin{array}{c}\text { Multivariate } \\
\text { analysis }\end{array}$ & OS & 0.765 & 0.371 & 1.577 \\
\hline PMID:25733977 & Osugi I & 2015 & [41] & Japan & Asian & $\mathrm{ADC}$ & 62 & & tissue & $\begin{array}{c}\text { Multivariate } \\
\text { analysis }\end{array}$ & DFS & 0.36 & 0.15 & 0.85 \\
\hline Study3 & LuS & 2015 & [42] & China & Asian & $\mathrm{ADC}$ & 62 & & tissue & $\begin{array}{c}\text { Multivariate } \\
\text { analysis }\end{array}$ & DFS & 0.36 & 0.15 & 0.87 \\
\hline PMID:26687391 & Shi SB & 2015 & [43] & China & Asian & LUAD & 76 & & blood & $\begin{array}{l}\text { Univariate } \\
\text { analysis }\end{array}$ & PFS & 2.06 & 1.19 & 3.57 \\
\hline Study2 & Zhou JL & 2017 & [35] & China & Asian & NSCLC & 48 & & serum & $\begin{array}{c}\text { Multivariate } \\
\text { analysis }\end{array}$ & PFS & 1.98 & 0.99 & 3.02 \\
\hline
\end{tabular}

target genes of miR-210: interleukin 6 (IL-6), C-X-C motif chemokine ligand 12 (CXCL12), G protein subunit $\gamma 11$ (GNG11), adenylate cyclase 9 (ADCY9), adrenoceptor $\beta 2$ (ADRB2), and cholinergic receptor muscarinic 2 (CHRM2).

Disease ontology analysis was conducted, and the top 10 items of the miR-210-related disease spectrum are shown in Fig. 18. In addition, gene alterations of miR-210 across NSCLC samples were examined using cBioPortal. As shown in Fig. 19, 8 (0.7\%) of 1144 cases had alterations (7 deep deletions and 1 amplification). Expression levels of the 6 potential target genes in GEPIA indicated that all of their mRNA levels had a reduced trend in NSCLC. The scatter point plots of the 6 target genes are presented in Fig. 20A-20F.

The protein expression levels of the 6 genes were searched for in HPA. The protein levels of 2 genes (CHRM2 and ADCY9) tended to be down-regulated in lung cancer compared to normal lung tissue (Figs. 21-22), while the remaining genes were not detected in the inspected samples of normal lung tissue and lung cancer tissue. Integrating this observation with the down-regulated mRNA levels of all 6 genes in NSCLC (Fig. 20), CHRM2 and ADCY9 are more likely to be target genes of miR-210 in lung cancer. However, due to the small 


\section{Cellular Physiology Cell Physiol Biochem 2018;46:925-952 \begin{tabular}{ll|l} 
aOI: 10.1159/000488823 & $\begin{array}{l}\text { ( ) } 2018 \text { The Author(s). Published by S. Karger AG, Basel } \\
\text { www.karger.com/cpb }\end{array}$ \\
\hline
\end{tabular} \\ He et al.: Clinical Value of MicroRNA-210 in NSCLC}

sample size provided by HPA and absence of statistical analysis, this hypothesis needs to be verified by future functional experiments.

\section{Discussion}

Lung cancer, according to estimates of the global burden of cancer, is the most common malignancy and the leading vital disease in male patients and it affects $17 \%$ of female patients with a $23 \%$ cancer-related mortality rate, which is equivalent to the burden of cervical cancer [44]. The currently used diagnostic methods of chest X-ray examination, computed tomography, magnetic resonance imaging, tumor marker detection in serum, and biopsy have limited efficacy, and therefore effective novel biomarkers of lung cancer are urgently required to improve its early diagnosis and treatment [29].

miR-210 has been explored extensively in miRNA research examining its correlation with cancers. An increasing number of studies have reported that miR210 plays an important role in the development of various types of cancer by regulating tumorigenesis and tumor growth, and miR-210 has been shown to exert its functions under hypoxic conditions $[45,46]$. A variety of hypoxic reactions that affect tumorgeneration are mediated by hypoxia-inducible factor (HIF).

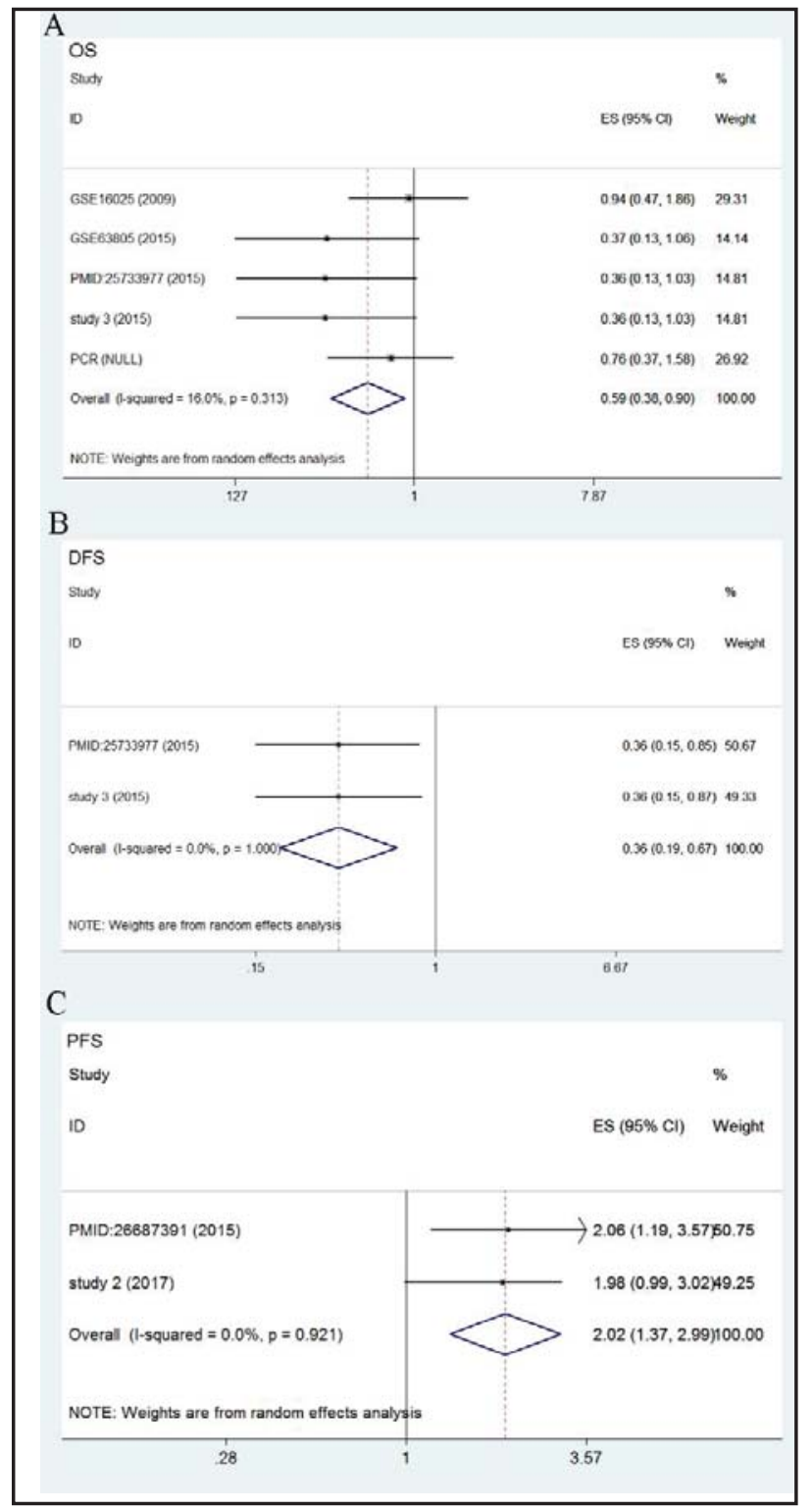

Fig. 12. Forest plots displaying the prognostic results of miR-210 in NSCLC. A: Forest plots of OS; B: DFS; and C: PFS.

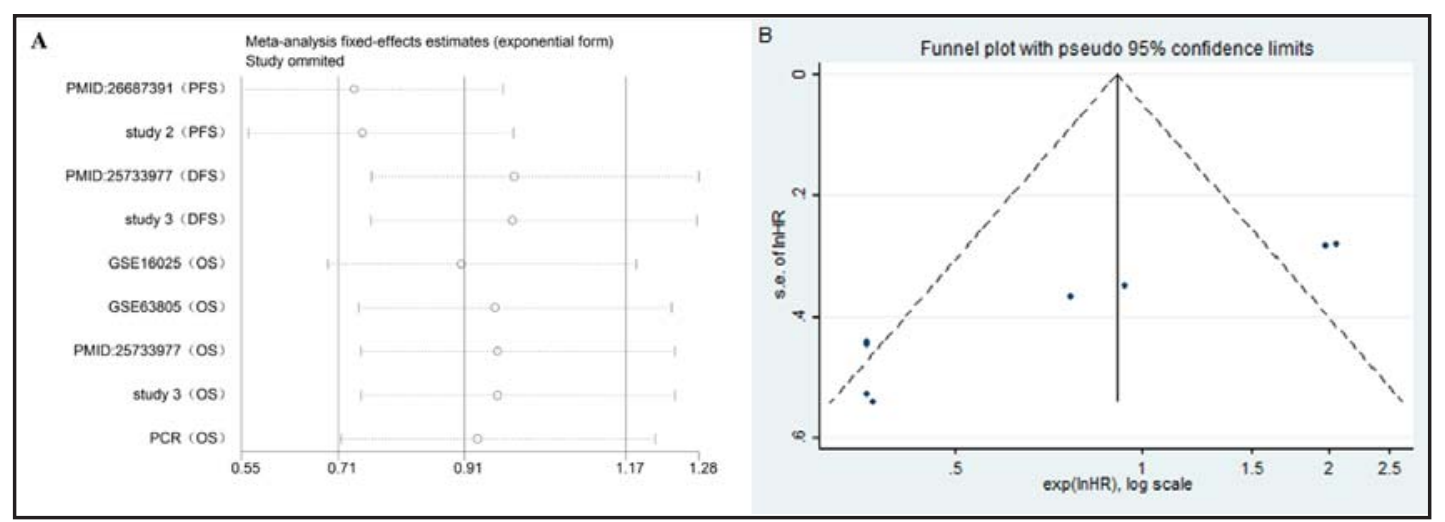

Fig. 13. A: Influence analysis. B: Funnel plot. 


\section{Cellular Physiology Cell Physiol Biochem 2018;46:925-952

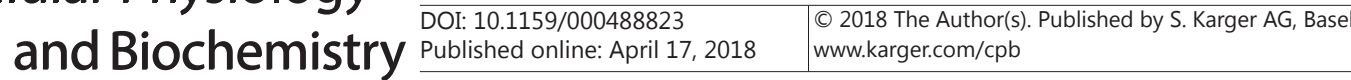 \\ He et al.: Clinical Value of MicroRNA-210 in NSCLC}

The promoter region of miR-210 contains a functional hypoxia-response element, to which HIF-1 $\alpha$ binds, thereby promoting tumor growth and cancer progression [47-50]. Kelly et al. found that glycerol-3-phosphate dehydrogenase 1-like (GPD1L), which not only reduces the stability of HIF- $1 \alpha$ but also is targeted directly by miR-210, has hydroxyprolinase activity [51]. miR-210 overexpression can reduce GPD1L expression under hypoxic conditions, so as to improve the stability of HIF- $1 \alpha$ and to enhance further the hypoxia-responsive capability of tumor cells.

miR-210 was recently shown to promote angiogenesis in hypoxic conditions [52]. Vascular endothelial growth factor (VEGF), an efficient pro-angiogenic protein, is negatively regulated by protein-tyrosine phosphatase 1B (PTP1B) through the de-phosphorylation of VEGFR2 in endothelial cells [53]. The overexpression of miR-210 can inhibit PTP1B; thus, VEGF can be expressed in hypoxic conditions to promote the regeneration of blood vessels $[54,55]$.

In addition, miR-210 overexpression reportedly regulates the progression of the cell cycle by inhibiting the expression of E2F3 and Myc-gene antagonistic factor Max network transcriptional repressor $[48,56,57]$. It was recently demonstrated that fibroblast growth factor receptor 1 and Homeobox protein A1, which are target proteins of miR-210, regulate cell proliferation $[58,59]$. Moreover, accumulating evidence has revealed that miR-210 can obstruct the DNA repair system by targeting the enzyme RAD52, which can repair DNA double-strand and single-strand gaps. miR-210 binds directly to the 3 '-untranslated region of RAD52 to repress its translation [60].

miR-210 was reported to be abnormally expressed in several kinds of human malignancy. A microarray profile and real-time qPCR analysis confirmed the outcome of patients in a large cohort study by Donnem et al., and demonstrated that miR-210 was up-regulated (fold change $=1.74$ ) and possibly associated with angiogenesis in NSCLC [61]. A series of microarray profile-based meta-analyses, which were published in 2012, 2013, and 2017, also came to the same conclusion that miR-210, along with several other miRNAs, was overexpressed in NSCLC [62-64]. In addition, the results of the present original estimation and metaanalysis results indicate that miR-210 was elevated in NSCLC, in agreement with the abovementioned studies. Our own first-hand RT-qPCR results for 125 paired cancerous and para-cancerous clinical tissues also confirmed this.

As for the diagnostic value of miR-210 for various cancers, it was reported that miR-210 is up-regulated in the serum of patients diagnosed with diffuse large B-cell lymphoma [65] or pancreatic ductal adeno-

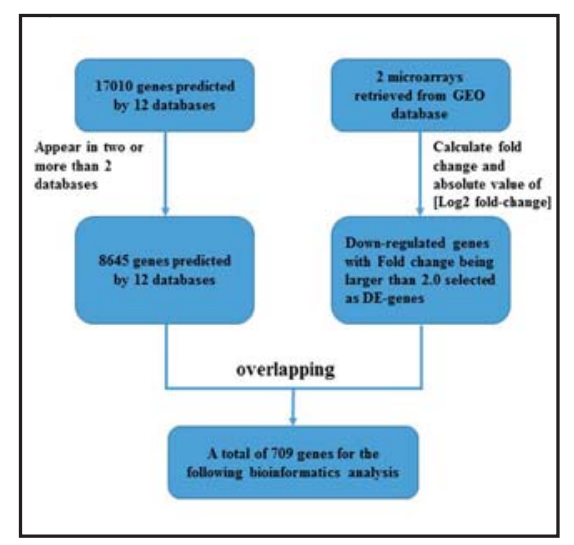

Fig. 14. Details of the process for target gene prediction.

Table 6. Prognostic value assessment: forest plots and publication bias analysis. OS: overall survival; DFS: disease-free survival; PFS: progression-free survival; CI: confidence interval; Fixed: fixed-effects model; Het $\mathrm{X}^{2}: \mathrm{X}^{2}$ of heterogeneity $\mathrm{Q}$ test; $\mathrm{P}_{\text {het }}: \mathrm{P}$ value of heterogeneity; Begg's $\mathrm{P}_{\text {bias }}: \mathrm{P}$ value of Begg's test

\begin{tabular}{|c|c|c|c|c|c|c|c|c|c|c|c|}
\hline \multirow{2}{*}{ Event type } & \multirow{2}{*}{$\begin{array}{c}\text { Study } \\
\text { number }\end{array}$} & \multirow{2}{*}{$\begin{array}{l}\text { Enrolled } \\
\text { number }\end{array}$} & \multirow{2}{*}{$\begin{array}{l}\text { Analysis } \\
\text { model }\end{array}$} & \multicolumn{4}{|c|}{ Overall estimate } & \multicolumn{3}{|c|}{ Heterogeneity } & \multirow{2}{*}{$\begin{array}{c}\text { Publication bias } \\
\text { Begg } P_{\text {bias }}\end{array}$} \\
\hline & & & & HR & 95\%CI(LL-UL) & $\mathrm{Z}$ & $P$ & $\mathrm{X}^{2}$ & $\mathrm{I}^{2}(\%)$ & $P_{\text {het }}$ & \\
\hline OS & 5 & 272 & Fixed & 0.602 & $0.410-0.884$ & 2.59 & 0.010 & 4.76 & $16.0 \%$ & 0.313 & 0.327 \\
\hline DFS & 2 & 124 & Fixed & 0.360 & $0.194-0.667$ & 3.24 & 0.001 & 0.00 & $0.00 \%$ & 1.000 & 1.000 \\
\hline PFS & 2 & 124 & Fixed & 2.020 & $1.366-2.988$ & 3.52 & 0.000 & 0.01 & $0.00 \%$ & 0.921 & 1.000 \\
\hline
\end{tabular}




\section{Cellular Physiology \\ Cell Physiol Biochem 2018;46:925-952 and Biochemistry

carcinoma [66]. A similar study by Xing et al. reported the early diagnostic value of miR-210 for lung squamous cell carcinoma [37]. A meta-analysis conducted by Yang et al. indicated the significant diagnostic value of miR-210 (AUC $=0.80$ ) for NSCLC by detecting its expression level in blood and sputum [67]. Likelwise, our study showed the significant diagnostic capacity of miR-210 in NSCLC by detecting its expression level in serum (AUC $=0.82$ ) and sputum (AUC $=0.81)$.

Foekens et al. examined the prognostic aspect of miR-210 and showed a positive correlation between elevated miR210 expression and the progression of estrogen receptor-positive and lymph node metastasisnegative breast cancer [68]. Our findings indicate that miR-210 overexpression was associated with poor PFS in NSCLC, while it was negatively related to $O S$ and DFS.

It is well known that miRNAs play a crucial role in posttranscriptional repression. miRNAs pair

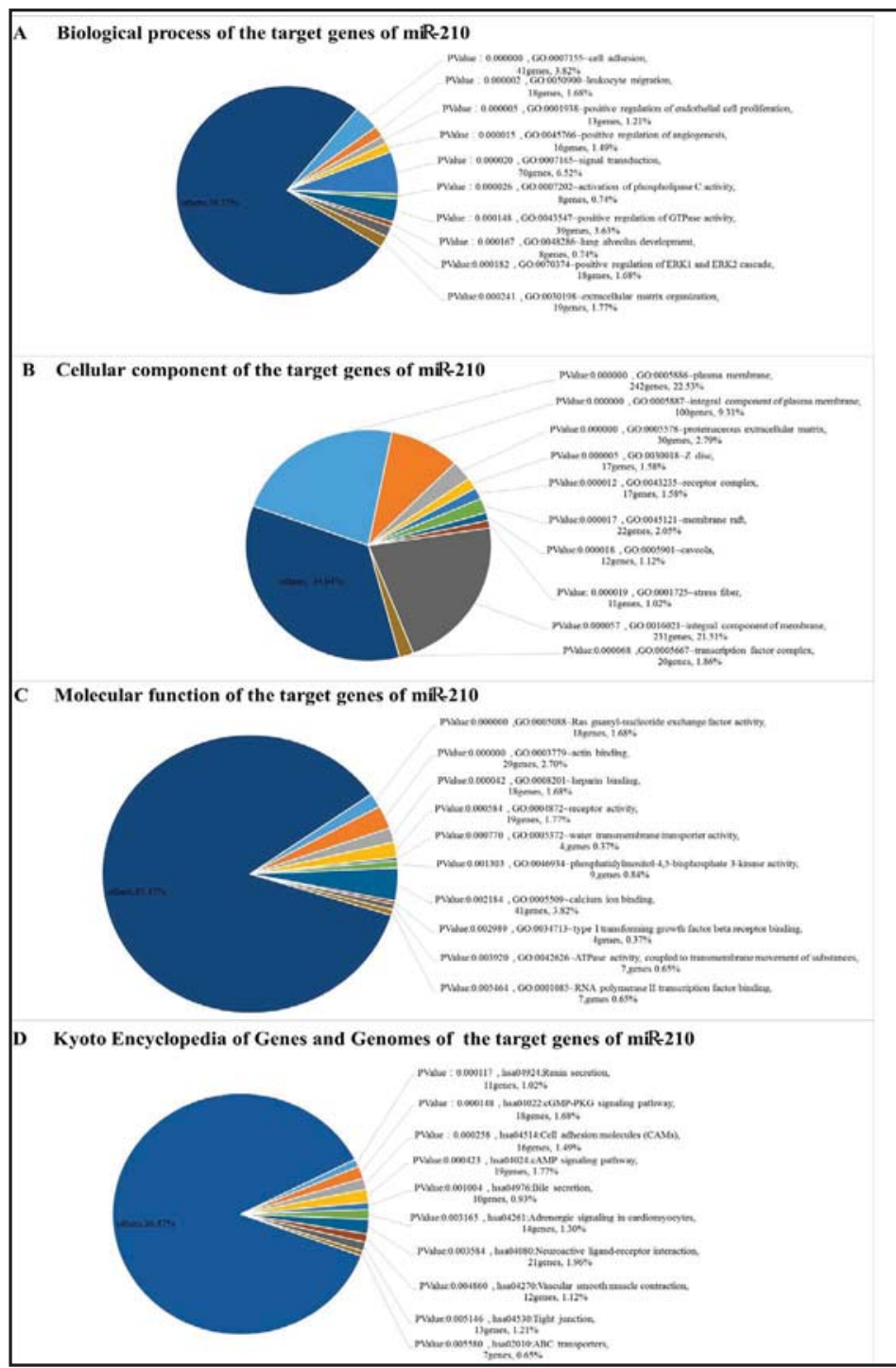

Fig. 15. Top 10 items. A: Biological process; B: Cellular component; C: Molecular function; and D: Kyoto Encyclopedia of Genes and Genomes. with the $3^{\prime}$-untranslated regions of their mRNA targets to control gene expression, the cell cycle, and development [69]. The majority of miRNAs are associated with the occurrence, progression, and prognosis of different types of cancer by repressing translation or inducing mRNA degradation [70]. It has also been demonstrated that there are different binding sites in one mRNA targeted by the same miRNA, which increases the possibility of finding real target genes and enables the experimental validation of miRNA target genes [71]. Thus, predicting the targets of miRNAs and further exploring their functions via bioinformatics analysis will help to generate a better understanding of the molecular mechanisms of miRNAs in cancer. The present study has made some contribution to the comprehensive recognition of the function of miR210 in NSCLC, but further study is required for a complete understanding. The expression levels of the 6 potential target genes (IL-6, GNG11, CXCL12, ADRB2, ADCY9, and CHRM2) were examined using GEPIA, showing a trend for their reduced expression in NSCLC (Fig. $20 \mathrm{~A}-20 \mathrm{E})$. Thus, it is likely that these 6 genes are potential targets of miR-210.

IL-6, located on 7p15.3, encodes a cytokine that induces the maturation of B cells and 


\section{Cellular Physiology \\ Cell Physiol Biochem 2018;46:925-952

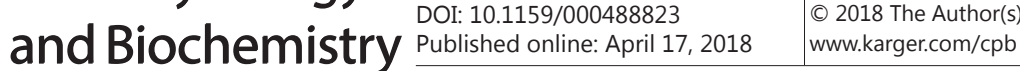

Fig. 16. Network analyses of the prospective target genes of miR-210 in A: biological process; B: cellular component; and C: molecular function. The intensity of the color indicates $\mathrm{P}$ value size, node refers to pathways, and node size is representative of the number of genes included in each node. A. Network analysis of miR-210 target genes in biological process. B. Network analysis of miR-210 target genes in cellular component. C. Network analysis of miR-210 target genes in molecular function.

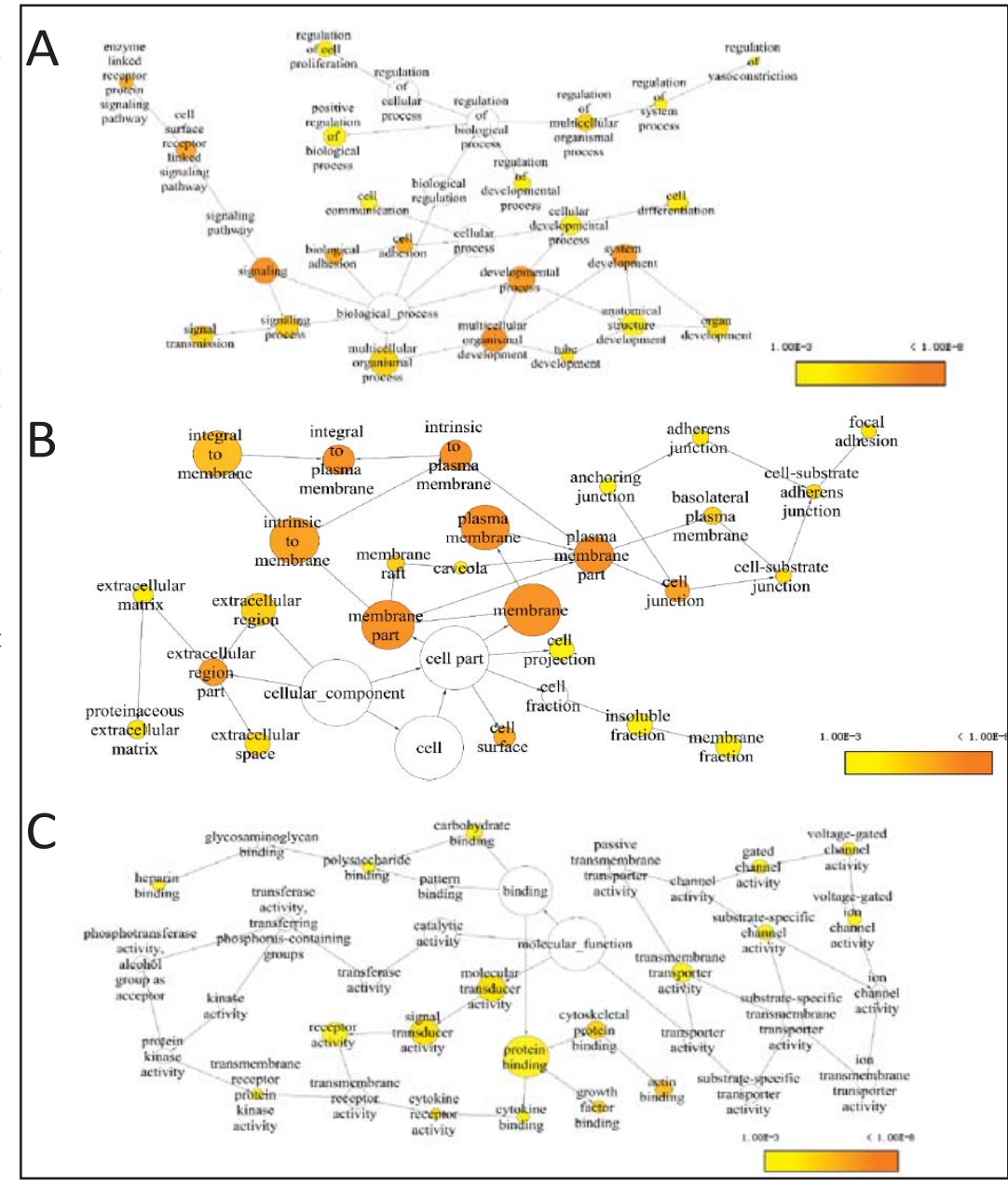

functions in various inflammatory processes [72]. IL-6 reportedly prevents the initiation of lung cancer by activating the transcription factor STAT3 to regulate lung macrophages and to preserve lung homeostasis [73]. However, Jiang et al. also demonstrated that IL-6 enhances the progression of lung cancer by inducing ATM phosphorylation and increasing the expression of MMP-3/MMP-13, thus enhancing cell migration and promoting the metastasis of lung tumor cells [74]. Liu et al. demonstrated that IL-6 can also boost the proliferation of lung cancer stem cells by suppressing the expression of cell cycle regulators [75]. All of these findings suggest that IL- 6 might be a crucial potential therapeutic target in lung cancer. Actually, Caetano et al. found that anti-IL- 6 treatment could be an alternative therapeutic strategy in lung cancer [76]. Interestingly, the reaction of patients with NSCLC to analgesics could be predicted by detecting a gene polymorphism of IL-6, which has shown significant value in improving the quality of life and prognosis of such patients [77]. However, as yet no studies have examined the relationship between IL- 6 and miR-210 in NSCLC.

GNG11, located on 7q21.3, encodes G protein subunit $\gamma$ 11, a member of the guanine nucleotide-binding protein (G protein) $\gamma$ family [78]. Hossain et al. discovered that GNG11 was strongly related to cell senescence [79], while Ruiz-Ballesteros et al. revealed that GNG11 expression was depressed in splenic marginal zone lymphoma [80]. GNG11 might act as a tumor suppressor in malignancies; however, the relationship between GNG11 and lung cancer has not been reported. Hence, experiments are needed to probe the role of GNG11 and miR-210 in lung cancer.

CXCL12, also known as SDF-1, is located on chromosome 10 and encodes an endocrine alpha chemokine in stromal cells. The encoded protein exerts its function by binding with 


\section{Cellular Physiology Cell Physiol Biochem 2018;46:925-952

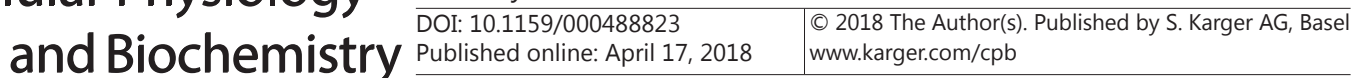 He et al.: Clinical Value of MicroRNA-210 in NSCLC}

Fig. 17. Proteinprotein interaction network of 80 hub genes.

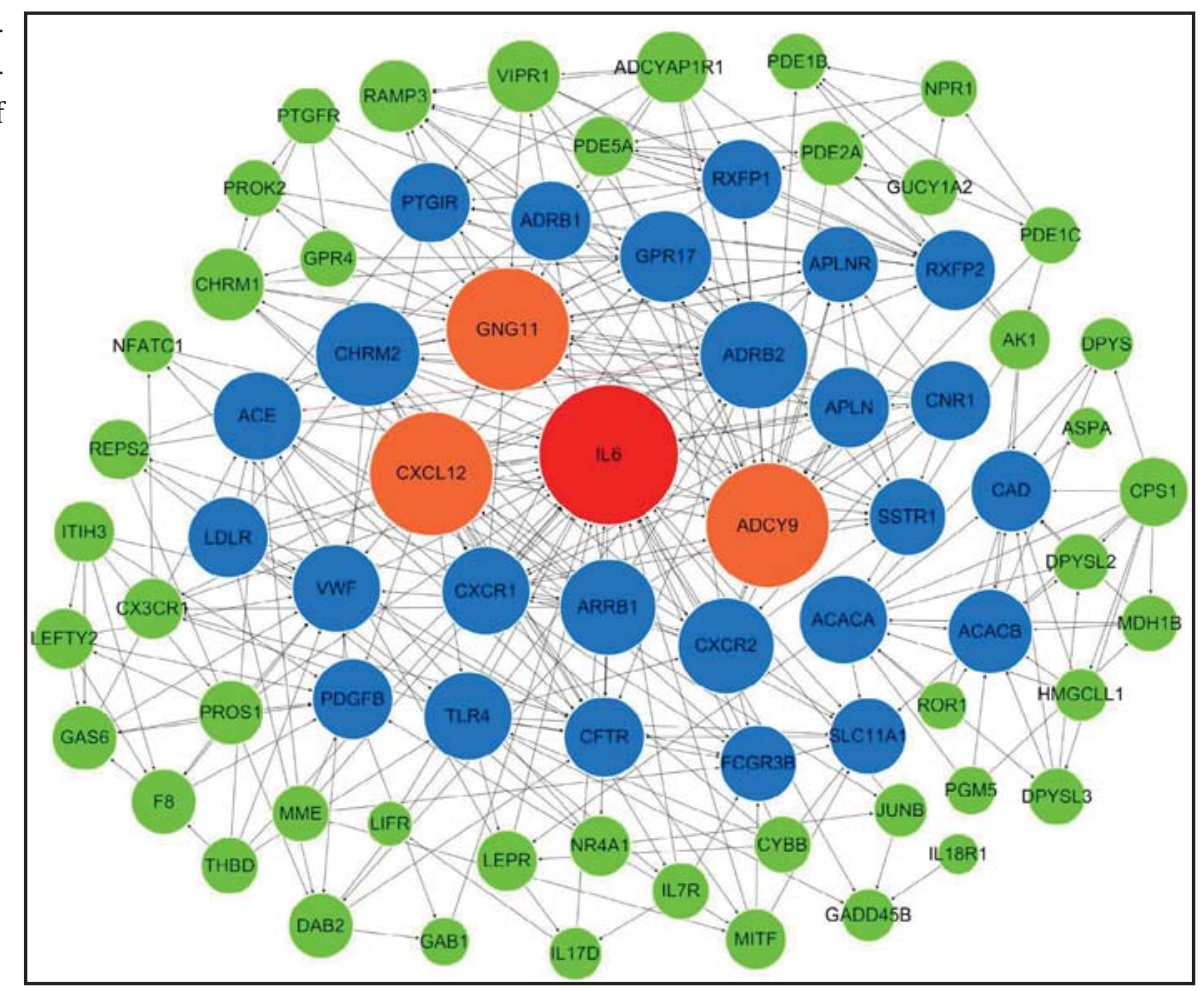

Fig. 18. Top 10 items of the miR210-related disease spectrum.
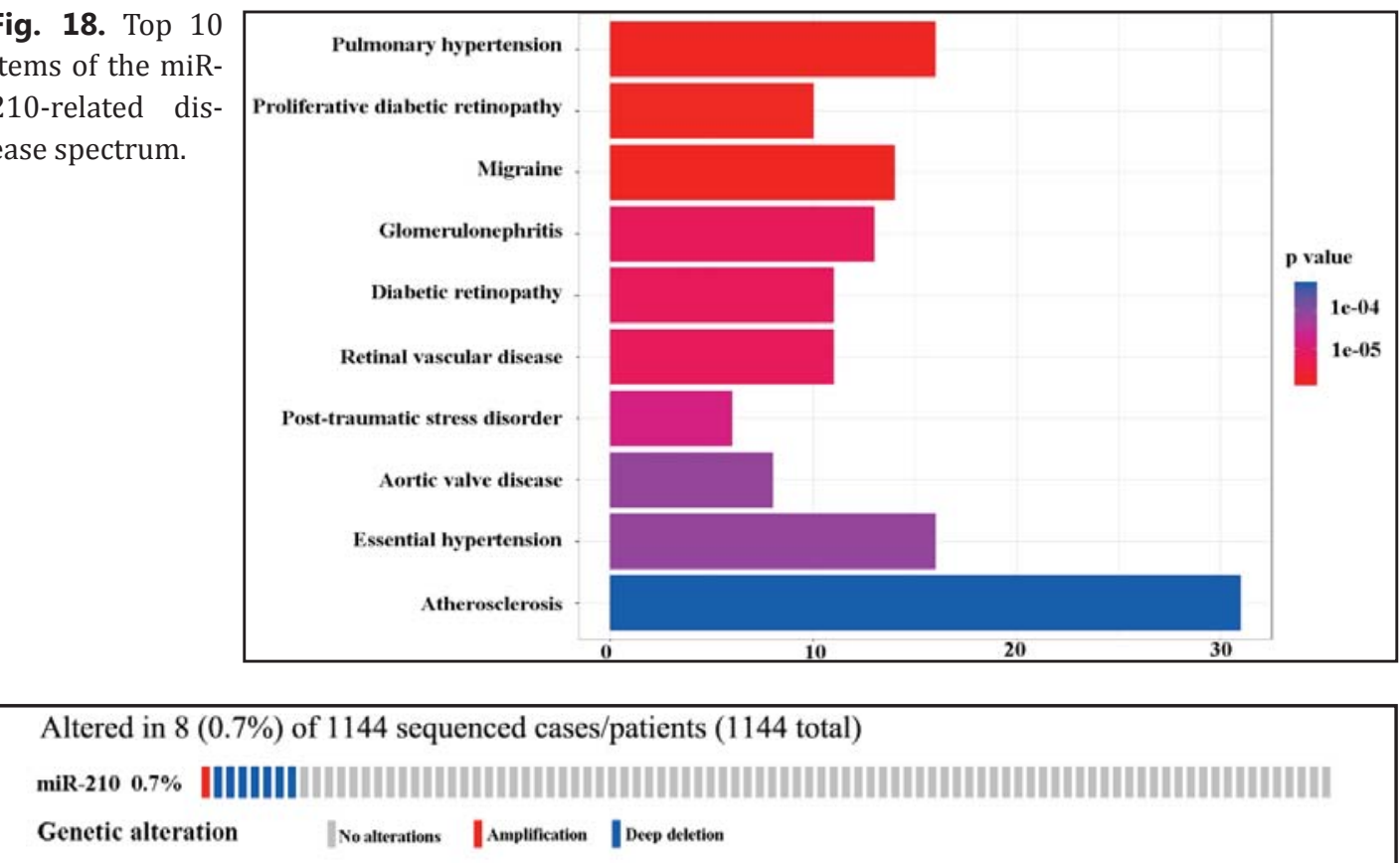

Fig. 19. Mutational alterations (amplification and deletion included) of miR-210 in 1144 NSCLC cases (OncoPrint tab from cBioPortal).

chemokine receptor 4 (CXCR4), a G protein-coupled receptor, in various biological processes, including embryogenesis, inflammatory response, and tumor progress and metastasis. Pathological roles for the CXCR4/CXCL12 axis have been demonstrated in various cancers, including breast cancer [81], kidney carcinoma [82], bone sarcoma [83], and NSCLC [84,

\section{KARGER}




\section{Cellular Physiology Cell Physiol Biochem 2018;46:925-952 \begin{tabular}{ll|l} 
and Biochemistry & $\begin{array}{l}\text { DOI: } 10.1159 / 000488823 \\
\text { Published online: April 17, } 2018\end{array}$ & $\begin{array}{l}\text { O } 2018 \text { The Author(s). Published by S. Karger AG, Basel } \\
\text { www.karger.com/cpb }\end{array}$ \\
\cline { 2 - 3 }
\end{tabular}}

85]. CXCR4/CXCL12 overexpression in these malignancies as well as in NSCLC may facilitate the local infiltration and dissemination of tumor cells.

ADRB2, also known as adrenoceptor $\beta$ receptor (ADRBR), is located on $5 \mathrm{q} 32$ and encodes the $\beta$-2-adrenergic receptor, a member of the $G$ protein-coupled receptor superfamily [86]. Gene polymorphisms, point mutations, and down-regulation of ADRB2 are closely related to obesity [87], nighttime asthma [88], and type 2 diabetes [89]. Wang et al. reported that ADRB2 has epidemiological significance in the development of lung cancer [90], and it may be a potential therapeutic target for lung cancer treatment [91]. More importantly, an agonist of ADRB2 enhanced sensitivity to cisplatin chemotherapy in an NSCLC cell line [92]. Unfortunately, no studies have examined the association between ADRB2 and miR-210 yet.

ADCY9, located on $16 \mathrm{p} 13.3$, is activated by the $\beta$-adrenergic receptor and catalyzes the formation of cyclic AMP from ATP [93]. It was speculated that it contributes to treatment of patients with mild to moderate asthma [94]. However, the relationship between ADCY9 and miR-210 in lung cancer has not been examined.

CHRM2, situated on chromosome 7, encodes a $\mathrm{G}$ protein-coupled receptor. CHRM2 interacts with acetylcholine and induces cellular biochemical processes, such as adenylate-cyclase inhibition, phosphoinositide degeneration, and potassium channel mediation. CHRM2 activation depresses cell proliferation and promotes apoptosis in glioblastoma cell lines [95]. Moreover, auto-paracrine non-neuronal acetylcholine, acting as a growth factor, stimulates tumor proliferation in NSCLC by activating CHRM2. In contrast, blocking CHRM2 arrests tumor cell growth in NSCLC [96, 97].

There are several highlights but also some limitations to this study. First, raw expression

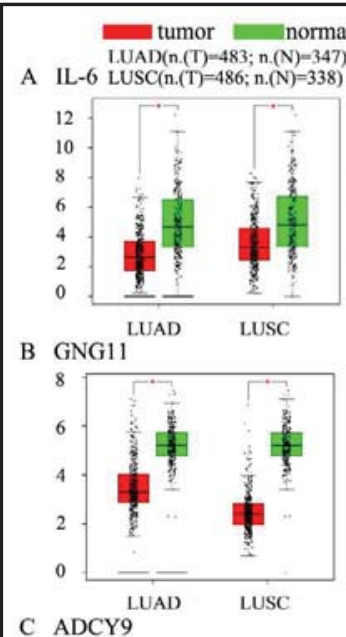

Interactive Bodymap tumor normal

C ADCY9

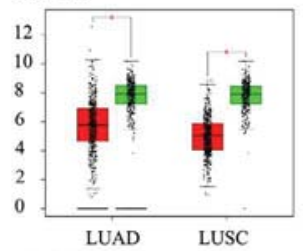

D ADRB2

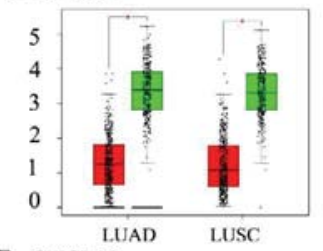

E CXCL12

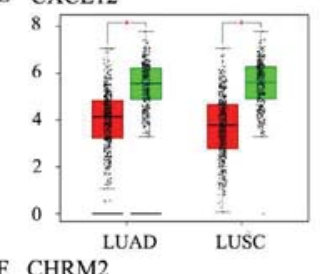

F CHRM2
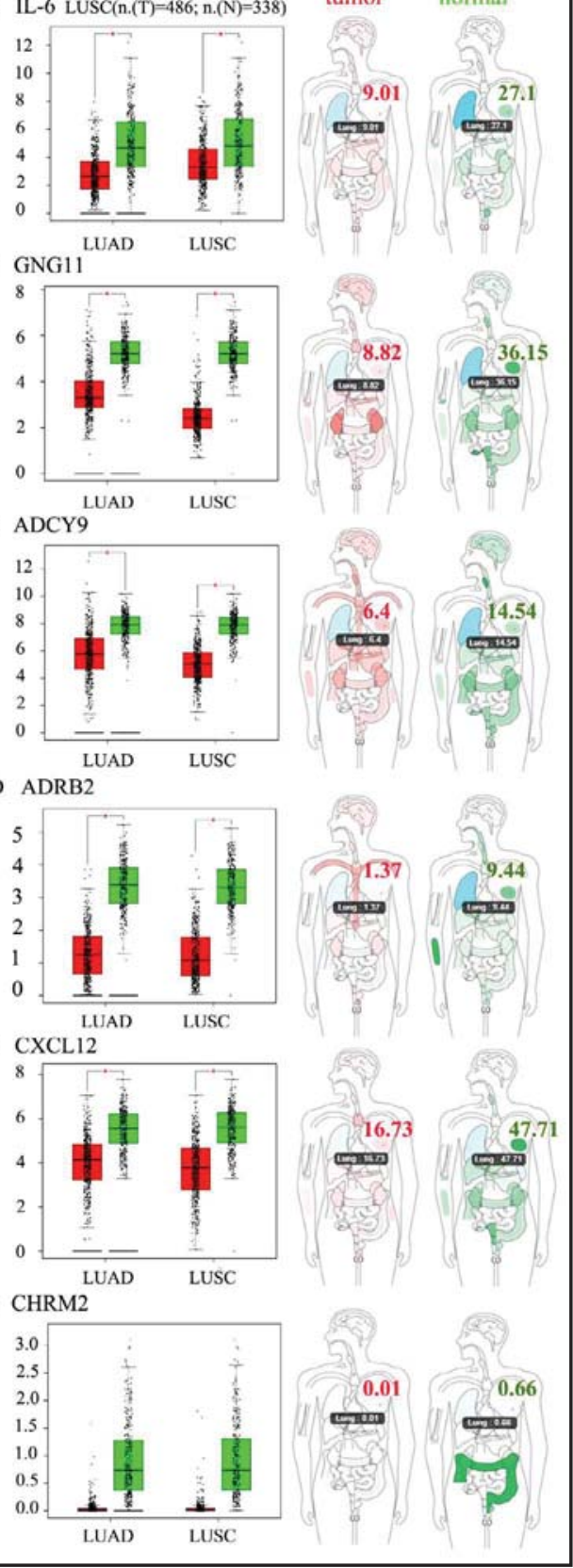

Fig. 20. Scatter point plots of the 6 target genes. data were extracted from the GEO and TCGA databases and were subjected to estimation for the mean and SD and significance testing. In addition, RT-qPCR was conducted on 125 paired NSCLC and adjacent paired samples as a means to validate the outcome obtained from the public databases; moreover, a meta-analysis based on raw data estimation outcomes and references was conducted to give an overall conclusion. According to the individual estimation results and overall pooled estimation, miR-210 was found to be consistently elevated in solid tissues from patients with NSCLC; however, this finding was varied in easily obtained blood samples. Besides, the number of enrolled samples in the different GEO datasets ranged greatly from 12 to 224; thus, finite deviation would exist in the estimation outcomes. As the detection platforms and operating 


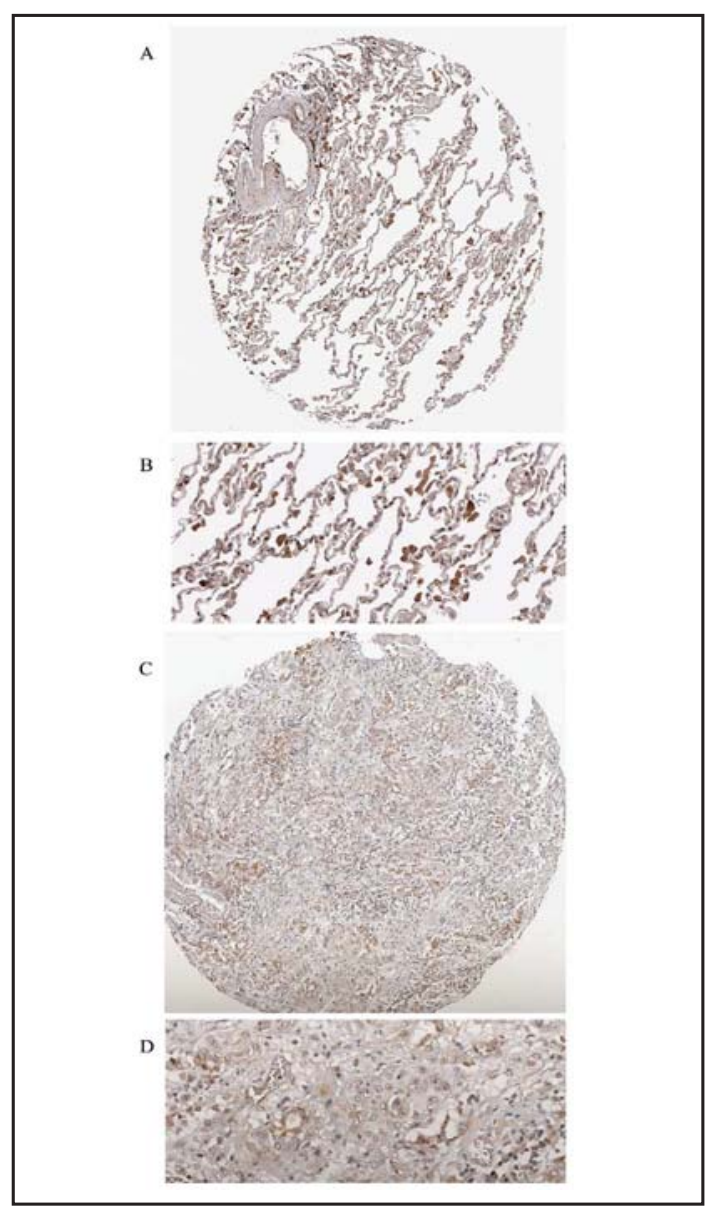

Fig. 21. Expression levels of CHRM2 protein in normal lung tissue and lung squamous cell carcinoma. A, B: Normal lung tissue: CAB022338, female, age 49 years, lung (T-28000), bronchus (T-26000), NOS (M-00100), patient ID: 2268, pneumocyte staining: low, intensity: weak, quantity: $>75 \%$, location: cytoplasmic/membranous nuclear. C, D: Lung squamous cell carcinoma: CAB022338, female, age 47 years, lung (T-28000), NOS (M80703), patient ID: 2100 , tumor cell staining: not detected, intensity: weak, quantity: $<25 \%$, location: nuclear.

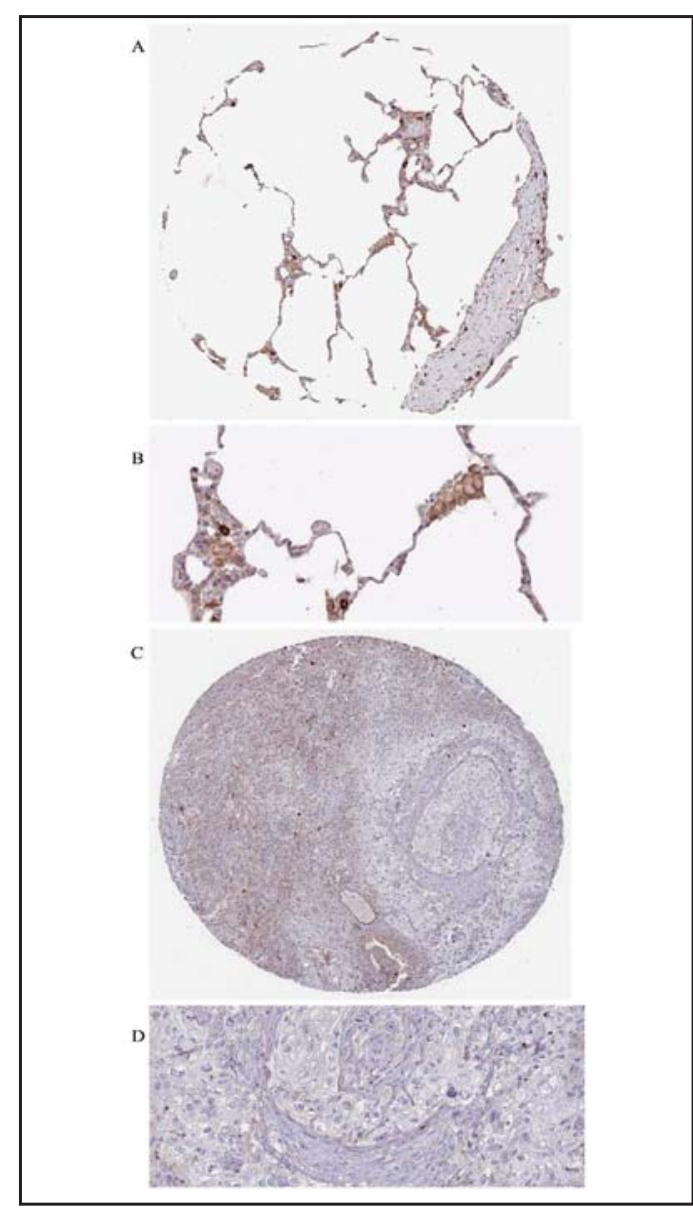

Fig. 22. Expression levels of ADCY9 protein in normal lung tissue and lung squamous cell carcinoma. A, B: Normal lung tissue: HPA044225, female, age 57 years, lung (T-28000), NOS (M00100), patient ID: 1678, pneumocyte staining: low, intensity: weak, quantity: $75-25 \%$, location: cytoplasmic/membranous. C, D: lung squamous cell carcinoma: HPA044225, female, age 69 years, lung (T-28000), NOS (M-80703), patient ID: 4194, tumor cell staining: not detected, intensity: weak, quantity: $<25 \%$, location: cytoplasmic/ membranous.

protocols were different, this had an inevitable confounding impact on the results, causing considerable inter-study heterogeneity, so consequently, we applied a random-effects model. Regarding the relationship between miR-210 and clinical parameters, the clinical status of the patients was not provided in every GEO datasets and therefore further validation is required to draw a conclusion. The scatter plots and ROC curves for each dataset were provided as intuitive measurements, as well as the forest plots and SROC curves for overall estimation. Thus, differences between the studies could be revealed easily, which facilitated further analysis. As for the function of miR-210 in NSCLC, although several hub-genes were selected from the predicted target genes, due to budgetary constraints, we were unable to validate the target genes and communication pathways of miR-210. 


\section{Cellular Physiology Cell Physiol Biochem 2018;46:925-952 \begin{tabular}{c|l} 
DOI: 10.1159/000488823 & $\begin{array}{l}\text { O 2018 The Author(s). Published by S. Karger AG, Basel } \\
\text { www.karger.com/cpb }\end{array}$ \\
\hline
\end{tabular}}

He et al.: Clinical Value of MicroRNA-210 in NSCLC

\section{Conclusion}

The results of our original estimations revealed that miR-210 expression was elevated in solid NSCLC tissues from GEO microarrays, a finding that concurs with that detected from TCGA data and our own RT-qPCR results. Conversely, because the results from different GEO microarrays varied, it is unclear whether miR-210 was overexpressed in easily obtained body fluids. Combining the original estimations, a meta-analysis revealed the overall elevation of miR-210 in NSCLC. Regarding the diagnostic value of miR-210, it showed significant diagnostic capacity in NSCLC by detecting its expression in serum and sputum. Elevated miR-210 expression in serum and sputum may be a potential biological marker for NSCLC patients. The prognostic meta-analysis revealed that miR-210 overexpression was associated with poor PFS in NSCLC, while it was negatively related to OS and DFS. Thus, rigorous studies with large samples are needed to explore whether miR-210 could be used as a prognostic index for NSCLC patients. Moreover, IL-6, CXCL12, GNG11, ADCY9, ADRB2, and CHRM2 were the most likely target molecules of miR-210. However, further studies are needed to gain a more comprehensive understanding of the role of miR-210 in NSCLC.

\section{Acknowledgements}

The study was supported by funds from National Natural Science Foundation of China (NSFC 81560469, NSFC 81360327), Natural Science Foundation of Guangxi, China (2017GXNSFAA198016, 2015GXNSFCA139009), Guangxi Medical University Training Program for Distinguished Young Scholars, Medical Excellence Award Funded by the Creative Research Development Grant from the First Affiliated Hospital of Guangxi Medical University, the International Communication of Guangxi Medical University Graduate Education (2017) and Guangxi Zhuang Autonomous Region University Student Innovative Plan (201710598001, 201710598080).

\section{Disclosure Statement}

No conflict of interests exists.

\section{References}

1 Charkiewicz R, Niklinski J, Claesen J, Sulewska A, Kozlowski M, Michalska-Falkowska A, Reszec J, Moniuszko M, Naumnik W, Niklinska W: Gene Expression Signature Differentiates Histology But Not Progression Status of Early-Stage NSCLC. Transl Oncol 2017;10:450-458.

-2 Siegel RL, Miller KD, Jemal A: Cancer Statistics 2017. CA Cancer J Clin 2017;67:7-30.

-3 Ul Hussain, M: Micro-RNAs (miRNAs): Genomic organisation, biogenesis and mode of action. Cell Tissue Res 2012;349:405-413.

4 Anglicheau D, Muthukumar T, Suthanthiran M: MicroRNAs: small RNAs with big effects. Transplantation 2010;90:105-112.

5 Voorhoeve PM: MicroRNAs: Oncogenes, tumor suppressors or master regulators of cancer heterogeneity? Biochim Biophys Acta 2010;1805:72-86.

6 Baehrecke EH: miRNAs: micro managers of programmed cell death. Curr Biol 2003;13:R473-475.

7 Ambros V: The functions of animal microRNAs. Nature 2004;431:350-355.

8 Michael MZ, O'Connor SM, van Holst NG, Young GP, James RJ: Reduced accumulation of specific mircoRNAs in colorectal neoplasia. Mol Cancer Res 2003;1:882-891.

-9 Croce CM: Causes and consequences of microRNA dysregulation in cancer. Nat Rev Genet 2009;10:704-714.

10 Wang W, Qu A, Liu W, Liu Y, Zheng G, Du L, Zhang X, Yang Y, Wang C, Chen X: Circulating miR-210 as a diagnostic and prognostic biomarker for colorectal cancer. Eur J Cancer Care (Engl) 2017;26. 


\section{Cellular Physiology Cell Physiol Biochem 2018;46:925-952 \begin{tabular}{c|l|l}
\hline DOI: 10.1159/000488823 & () 2018 The Author(s). Published by S. Karger AG, Basel
\end{tabular}}

He et al. Clinical Value of MicroRNA-210 in NSCLC

11 Sun W, Zhao L, Song X, Zhang J, Xing Y, Liu N, Yan Y, Li Z, Lu Y, Wu J, Li L, Xiao Y, Tian X, Li T, Guan Y, Wang Y, Liu B: MicroRNA-210 Modulates the Cellular Energy Metabolism Shift During H202-Induced Oxidative Stress by Repressing ISCU in H9c2 Cardiomyocytes. Cell Physiol Biochem 2017;43:383-384.

12 Ke HL, Li WM, Lin HH, Hsu WC, Hsu YL, Chang LL, Huang CN, Li CC, Chang HP, Yeh HC, Li CF, Wu WJ: Hypoxia-regulated MicroRNA-210 Overexpression is Associated with Tumor Development and Progression in Upper Tract Urothelial Carcinoma. Int J Med Sci 2017;14:578-584.

-13 Satzger I, Mattern A, Kuettler U, Weinspach D, Voelker B, Kapp A, Gutzmer R: MicroRNA-15b represents an independent prognostic parameter and is correlated with tumor cell proliferation and apoptosis in malignant melanoma. Int J Cancer 2010;126:2553-2562.

14 Amponsah PS, Fan P, Bauer N, Zhao Z, Gladkich J, Fellenberg J, Herr I: microRNA-210 overexpression inhibits tumor growth and potentially reverses gemcitabine resistance in pancreatic cancer. Cancer Let 2017;388:107-117.

15 Hong L, Yang J, Han Y, Lu Q Cao J, Syed L: High expression of miR-210 predicts poor survival in patients with breast cancer: a meta-analysis. Gene 2012;507:135-138.

16 Liu TY, Zhang H, Du SM, Li J, Wen XH: Expression of microRNA-210 in tissue and serum of renal carcinoma patients and its effect on renal carcinoma cell proliferation, apoptosis, and invasion. Genet Mol Res 2016;15:15017746.

17 Li XX, Liu Y, Meng HH, Wang XW: Expression of miR-210 in senile COPD complicating primary lung cancer. Eur Rev Med Pharmacol Sci 2017;21:38-42.

-18 Võsa U, Vooder T, Kolde R, Vilo J, Metspalu A, Annilo T: Meta-analysis of microRNA expression in lung cancer. Int J Cancer 2013;132:2884-2893.

19 Li C, Yin Y, Liu X, Xi X, Xue W, Qu Y: Non-small cell lung cancer associated microRNA expression signature: integrated bioinformatics analysis, validation and clinical significance. Oncotarget 2017;8:24564-25478.

-20 Zhu W, Zhou K, Zha Y, Chen D, He J, Ma H, Liu X, Le H, Zhang Y: Diagnostic Value of Serum miR-182, miR183, miR-210, and miR-126 Levels in Patients with Early-Stage Non-Small Cell Lung Cancer. PLoS One 2016;11:e0153046.

21 Higgins JP, Thompson SG, Deeks JJ, Altman DG: Measuring inconsistency in meta-analyses. BMJ 2003;327:557-560.

22 Higgins JP, Thompson SG: Quantifying heterogeneity in a meta-analysis. Stat Med 2002;21:1539-558.

-23 Lachin JM: Power and sample size evaluation for the Cochran-Mantel-Haenszel mean score (Wilcoxon rank sum) test and the Cochran-Armitage test for trend. Stat Med 2011;30:3057-3066.

24 Schou IM, Marschner IC: Meta-analysis of clinical trials with early stopping: an investigation of potential bias. Stat Med 2013;32:4859-4874.

25 Galbraith RF: A note on graphical presentation of estimated odds ratios from several clinical trials. Stat Med 1988;7:889-894.

-26 Egger M, Davey Smith G, Schneider M, Minder C: Bias in meta-analysis detected by a simple, graphical test. BMJ 1997;315:629-634

27 Zamora J, Abraira V, Muriel A, Khan K, Coomarasamy A: Meta-DiSc: a software for meta-analysis of test accuracy data. BMC Med Res Methodol 2006;6:31.

28 Reitsma JB, Glas AS, Rutjes AW, Scholten RJ, Bossuyt PM, Zwinderman AH: Bivariate analysis of sensitivity and specificity produces informative summary measures in diagnostic reviews. J Clin Epidemiol 2005;58:982-990.

29 Wang X, Zhi X, Zhang Y, An G, Feng G: Role of plasma MicroRNAs in the early diagnosis of non-small-cell lung cancers: a case-control study. J Thorac Dis 2016;8:1645-1652.

-30 Li ZH, Zhang H, Yang ZG, Wen GQ Cui YB, Shao GG: Prognostic significance of serum microRNA-210 levels in nonsmall-cell lung cancer. J Int Med Res 2013;41:1437-1444.

-31 Anjuman N, Li N, Guarnera M, Stass SA, Jiang F: Evaluation of lung flute in sputum samples for molecular analysis of lung cancer. Clin Transl Med 2013;2:15.

-32 Shen J, Todd NW, Zhang H, Yu L, Lingxiao X, Mei Y, Guarnera M, Liao J, Chou A, Lu CL, Jiang Z, Fang H, Katz RL, Jiang F: Plasma microRNAs as potential biomarkers for non-small-cell lung cancer. Lab Invest 2011;91:579-587.

-33 Shen J, Liu Z, Todd NW, Zhang H, Liao J, Yu L, Guarnera MA, Li R, Cai L, Zhan M, Jiang F: Diagnosis of lung cancer in individuals with solitary pulmonary nodules by plasma microRNA biomarkers. BMC Cancer 2011;11:374. 


\section{Cellular Physiology Cell Physiol Biochem 2018;46:925-952 \begin{tabular}{c|l|l}
\hline DOI: 10.1159/000488823 & (0) 2018 The Author(s). Published by S. Karger AG, Basel \\
and Biochemistry
\end{tabular} and Biochemistry Published online: April 17, 2018 www.karger.com/cpb}

He et al.: Clinical Value of MicroRNA-210 in NSCLC

-34 Xia XB, Li J, Wang Y: Evaluation of clinical value of plasma miRNA-20a and miRNA-210 in diagnosis of lung cacer. J of Jiangsu Univer 2017, 27:47-52. DOI: 10.13312/j.issn.1671-7783.y169301.

-35 Zhou JL, Deng SK: Clinical application value of combined detection of serum miRNA-210 and miRNA-2l in non-small cell lung cancer. Chongqong Med 2017; 46:908-912.DOI: 10.3969/j.issn.1671-8348.2017.07.014.

-36 Shen J, Liao J, Guarnera MA, Fang H, Cai L, Stass SA, Jiang F: Analysis of MicroRNAs in sputum to improve computed tomography for lung cancer diagnosis. J Thorac Oncol 2014;9:33-40.

-37 Xing L, Todd NW, Yu L, Fang H, Jiang F: Early detection of squamous cell lung cancer in sputum by a panel of microRNA markers. Mod Pathol 2010;23:1157-1164.

38 Xing L, Su J, Guarnera MA, Zhang H, Cai L, Zhou R, Stass SA, Jiang F: Sputum microRNA biomarkers for identifying lung cancer in indeterminate solitary pulmonary nodules. Clin Cancer Res 2015;21:484-489.

-39 Li N, Ma J, Guarnera MA, Fang H, Cai L, Jiang F: Digital PCR quantification of miRNAs in sputum for diagnosis of lung cancer. J Cancer Res Clin Oncol 2014;140:145-150.

40 Su Y, Fang H, Jiang F: Integrating DNA methylation and microRNA biomarkers in sputum for lung cancer detection. Clin Epigenetics 2016;8:109.

-41 Osugi J, Kimura Y, Owada Y, Inoue T, Watanabe Y, Yamaura T, Fukuhara M, Muto S, Okabe N, Matsumura Y, Hasegawa T, Yonechi A, Hoshino M, Higuchi M, Shio Y, Suzuki H, Gotoh M: Prognostic Impact of HypoxiaInducible miRNA-210 in Patients with Lung Adenocarcinoma. J Oncol 2015;2015:316745.

42 Lu S, Zu Z, Wang Y, Feng Z, Lu Q Zhang T, Li XF: Prognostic Impact of miRNA-210 for Squamous Cell Carcinoma and Adenocarcinoma of Lung. Progress in Modern Biomed 2015, 15:6095-6100. DOI: 10.13241/j.cnki. pmb.2015.31.026.

43 Shi SB, Wang M, Tian J, Li R, Chang CX, Qi JL: MicroRNA 25, microRNA 145, and microRNA 210 as biomarkers for predicting the efficacy of maintenance treatment with pemetrexed in lung adenocarcinoma patients who are negative for epidermal growth factor receptor mutations or anaplastic lymphoma kinase translocations. Transl Res 2016;170:1-7.

44 Global Burden of Disease Cancer Collaboration, Fitzmaurice C, Dicker D, Pain A, Hamavid H, Moradi-Lakeh M, MacIntyre MF, Allen C, Hansen G, Woodbrook R, Wolfe C, Hamadeh RR, Moore A, Werdecker A, Gessner BD, Te Ao B, McMahon B, Karimkhani C, Yu C, Cooke GS, Schwebel DC, Carpenter DO: The Global Burden of Cancer 2013 JAMA Oncol 2015;1:505-527.

45 Li C, Gao Y, Zhang K, Chen J, Han S, Feng B, Wang R, Chen L: Multiple Roles of MicroRNA-100 in Human Cancer and its Therapeutic Potential. Cell Physiol Biochem 2015;37:2143-2159.

46 Chan YC, Banerjee J, Choi SY, Sen CK: miR-210: the master hypoxamir. Microcirculation 2012;19:215-223.

47 Camps C, Buffa FM, Colella S, Moore J, Sotiriou C, Sheldon H, Harris AL, Gleadle JM, Ragoussis J: hsamiR-210 Is induced by hypoxia and is an independent prognostic factor in breast cancer. Clin Cancer Res 2008;14:1340-1348.

48 Zhang Z, Sun H, Dai H, Walsh RM, Imakura M, Schelter J, Burchard J, Dai X, Chang AN, Diaz RL, Marszalek JR, Bartz SR, Carleton M, Cleary MA, Linsley PS, Grandori C: MicroRNA miR-210 modulates cellular response to hypoxia through the MYC antagonist MNT. Cell Cycle 2009;8:2756-2768.

49 Kai AK, Chan LK, Lo RC, Lee JM, Wong CC, Wong JC, Ng IO: Down-regulation of TIMP2 by HIF-1 $\alpha / \mathrm{miR}-210$ / HIF-3 $\alpha$ regulatory feedback circuit enhances cancer metastasis in hepatocellular carcinoma. Hepatology 2016;64:473-87.

50 Cui H, Seubert B, Stahl E, Dietz H, Reuning U, Moreno-Leon L, Ilie M, Hofman P, Nagase H, Mari B, Krüger A: Tissue inhibitor of metalloproteinases- 1 induces a pro-tumourigenic increase of miR-210 in lung adenocarcinoma cells and their exosomes. Oncogene 2015;34:3640-3650.

-51 Kelly TJ, Souza AL, Clish CB, Puigserver P: A hypoxia-induced positive feedback loop promotes hypoxiainducible factor 1alpha stability through miR-210 suppression of glycerol-3-phosphate dehydrogenase 1-like. Mol Cell Biol 2011;31:2696-2706.

-52 Yang Y, Zhang J, Xia T, Li G, Tian T, Wang M, Wang R, Zhao L, Yang Y, Lan K, Zhou W: MicroRNA-210 promotes cancer angiogenesis by targeting fibroblast growth factor receptor-like 1 in hepatocellular carcinoma. Oncol Rep 2016;36:2553-2562.

-53 Nakamura Y, Patrushev N, Inomata H, Mehta D, Urao N, Kim HW, Razvi M, Kini V, Mahadev K, Goldstein BJ, McKinney R, Fukai T, Ushio-Fukai M: Role of protein tyrosine phosphatase 1B in vascular endothelial growth factor signaling and cell-cell adhesions in endothelial cells. Circ Res 2008;102:1182-1191.

-54 Hu S, Huang M, Li Z, Jia F, Ghosh Z, Lijkwan MA, Fasanaro P, Sun N, Wang X, Martelli F, Robbins RC, Wu JC: MicroRNA-210 as a novel therapy for treatment of ischemic heart disease. Circulation 2010;122:S124-131. 


\section{Cellular Physiology Cell Physiol Biochem 2018;46:925-952 \begin{tabular}{l|l}
\hline DOI: 10.1159/000488823 & (c) 2018 The Author(s). Published by S. Karger AG, Basel \\
and Biochemistry Published
\end{tabular} and Biochemistry Published online: April 17, 2018 www.karger.com/cpb}

He et al:: Clinical Value of MicroRNA-210 in NSCLC

55 Liu F, Lou YL, Wu J, Ruan QF, Xie A, Guo F, Cui SP, Deng ZF, Wang Y: Upregulation of MicroRNA-210 Regulates Renal Angiogenesis Mediated by Activation of VEGF Signaling Pathway under Ischemia/Perfusion Injury in vivo and in vitro. Kidney Blood Press Res 2011;35:182-191.

-56 Biswas S, Roy S, Banerjee J, Hussain SR, Khanna S, Meenakshisundaram G, Kuppusamy P, Friedman A, Sen CK: Hypoxia inducible microRNA 210 attenuates keratinocyte proliferation and impairs closure in a murine model of ischemic wounds. Proc Natl Acad Sci U S A 2010;107:6976-6981.

-57 Giannakakis A, Sandaltzopoulos R, Greshock J, Liang S, Huang J, Hasegawa K, Li C, O’Brien-Jenkins A, Katsaros D, Weber BL, Simon C, Coukos G, Zhang L: Mir-210 links hypoxia with cell cycle regulation and is deleted in human epithelial ovarian cancer. Cancer Biology and Therapy 2008;7:255.

-58 Huang X, Ding L, Bennewith KL, Tong RT, Welford SM, Ang KK, Story M, Le QT, Giaccia AJ: Hypoxia-inducible mir-210 regulates normoxic gene expression involved in tumor initiation. Mol Cell 2009;35:856-867.

59 Tsuchiya S, Fujiwara T, Sato F, Shimada Y, Tanaka E, Sakai Y, Shimizu K, Tsujimoto G: MicroRNA-210 regulates cancer cell proliferation through targeting fibroblast growth factor receptor-like 1 (FGFRL1). J Biol Chem 2011;286:420-428.

60 Crosby ME, Kulshreshtha R, Ivan M, Glazer PM: MicroRNA regulation of DNA repair gene expression in hypoxic stress. Cancer Res 2009;69:1221-1229.

-61 Donnem T, Fenton CG, Lonvik K, Berg T, Eklo K, Andersen S, Stenvold H, Al-Shibli K, Al-Saad S, Bremnes RM, Busund LT: MicroRNA signatures in tumor tissue related to angiogenesis in non-small cell lung cancer. PLoS One 2012; 7:e29671.

62 Guan P, Yin Z, Li X, Wu W, Zhou B: Meta-analysis of human lung cancer microRNA expression profiling studies comparing cancer tissues with normal tissues. J Exp Clin Cancer Res 2012;31:54.

-63 Võsa U, Vooder T, Kolde R, Vilo J, Metspalu A, Annilo T: Meta-analysis of microRNA expression in lung cancer. Int J Cancer 2013;132:2884-2893.

-64 Li C, Yin Y, Liu X, Xi X, Xue W, Qu Y: Non-small cell lung cancer associated microRNA expression signature: integrated bioinformatics analysis, validation and clinical significance. Oncotarget 2017;8:24564-24578.

65 Lawrie CH, Gal S, Dunlop HM, Pushkaran B, Liggins AP, Pulford K, Banham AH, Pezzella F, Boultwood J, Wainscoat JS, Hatton CS, Harris AL: Detection of elevated levels of tumour-associated microRNAs in serum of patients with diffuse large B-cell lymphoma. Br J Haematol 2008;5:672-675.

66 Wang J, Chen J, Chang P, LeBlanc A, Li D, Abbruzzesse JL, Frazier ML, Killary AM, Sen S: MicroRNAs in plasma of pancreatic ductal adenocarcinoma patients as novel blood-based biomarkers of disease. Cancer Prev Res 2009;9:807-813.

67 Yang H, Wang H, Zhang C, Tong Z: The accuracy of microRNA-210 in diagnosing lung cancer: a systematic review and meta-analysis. Oncotarget 2016;7:63283-63293.

-68 Foekens JA, Sieuwerts AM, Smid M, Look MP, de Weerd V, Boersma AW, Klijn JG, Wiemer EA, Martens JW: Four miRNAs associated with aggressiveness of lymph node-negative, estrogen receptor-positive human breast cancer. Proc Natl Acad Sci USA 2008;05:13021-13026.

69 Kloosterman WP, Plasterk RH: The diverse functions of microRNAs in animal development and disease. Dev Cell 2006;11:441-1450.

70 Calin GA, Croce CM: MicroRNA signatures in human cancers. Nat Rev Cancer 2006;6:857-866.

71 Flamant S, Ritcxhie W, Guilhot J, Holst J, Bonnet ML, Chomel JC, Guilhot F, Turhan AG, Rasko JE: Micro-RNA response to imatinib mesylate in patients with chronic myeloid leukemia. Haematologica 2010;95:13251333.

72 Scheller J, Ohnesorge N, Rose-John S: Interleukin-6 trans-signalling in chronic inflammation and cancer. Scand J Immunol 2006;63:321-329.

-73 Qu Z, Sun F, Zhou J, Li L, Shapiro SD, Xiao G: Interleukin-6 Prevents the Initiation but Enhances the Progression of Lung Cancer. Cancer Res 2015;75:3209-3215.

-74 Jiang YN, Yan HQ, Huang XB, Wang YN, Li Q Gao FG: Interleukin 6 trigged ataxia-telangiectasia mutated activation facilitates lung cancer metastasis via MMP-3/MMP-13 up-regulation. Oncotarget 2015;6:4071940733.

75 Liu CC, Lin JH, Hsu TW, Su K, Li AF, Hsu HS, Hung SC: IL-6 enriched lung cancer stem-like cell population by inhibition of cell cycle regulators via DNMT1 upregulation. Int J Cancer 2015;136:547-559. 


\section{Cellular Physiology Cell Physiol Biochem 2018;46:925-952 \begin{tabular}{c|l|l}
\hline DOI: 10.1159/000488823 & ( ) 2018 The Author(s). Published by S. Karger AG, Basel \\
and Biochemistry Published
\end{tabular} and Biochemistry Published online: April 17, 2018 www.karger.com/cpb}

He et al.: Clinical Value of MicroRNA-210 in NSCLC

76 Caetano MS, Zhang H, Cumpian AM, Gong L, Unver N, Ostrin EJ, Daliri S, Chang SH, Ochoa CE, Hanash S, Behrens C, Wistuba II, Sternberg C, Kadara H, Ferreira CG, Watowich SS, Moghaddam SJ: IL6 Blockade Reprograms the Lung Tumor Microenvironment to Limit the Development and Progression of K-rasMutant Lung Cancer. Cancer Res 2016;76:3189-3199.

-77 Zhao K, Xu J, Tian H: Correlation analysis between an IL-6 genetic polymorphism and non-small cell lung cancer prognosis. Genet Mol Res 2016;15:15017021.

-78 Takauji Y, Kudo I, En A, Matsuo R, Hossain MN, Nakabayashi K, Miki K, Fujii M, Ayusawa D: GNG11 (G-protein subunit $\gamma 11$ ) suppresses cell growth with induction of reactive oxygen species and abnormal nuclear morphology in human SUSM-1 cells. Biochem Cell Biol 2017;95:517-523.

-79 Hossain MN, Sakemura R, Fujii M, Ayusawa D: G-protein gamma subunit GNG11 strongly regulates cellular senescence. Biochem Biophys Res Commun 2006;351:645-650.

-80 Ruiz-Ballesteros E, Mollejo M, Rodriguez A, Camacho FI, Algara P, Martinez N, Pollán M, Sanchez-Aguilera A, Menarguez J, Campo E, Martinez P, Mateo M, Piris MA: Splenic marginal zone lymphoma: proposal of new diagnostic and prognostic markers identified after tissue and cDNA microarray analysis. Blood 2005;106:1831-1838.

-81 Okuyama KM, de Oliveira CE, Banin-Hirata BK, Losi-Guembarovski R, Brajão de Oliveira K, Amarante MK, Watanabe MA: Immunohistochemical expression of CXCR4 on breast cancer and its clinical significance. Anal Cell Pathol (Amst) 2015;2015:891020.

82 de Vivar Chevez AR, Finke J, Bukowski R: The role of inflammation in kidney cancer. Adv Exp Med Biol 2014;816:197-234.

83 Liao YX, Zhou CH, Zeng H, Zuo DQ, Wang ZY, Yin F, Hua YQ Cai ZD: The role of the CXCL12-CXCR4/CXCR7 axis in the progression and metastasis of bone sarcomas (Review). Int J Mol Med 2013;32:1239-1246.

84 Samarendra H, Jones K, Petrinic T, Silva MA, Reddy S, Soonawalla Z, Gordon-Weeks A: A meta-analysis of CXCL12 expression for cancer prognosis.Br J Cancer 2017; 117:124-135.

-85 Wang Z, Sun J, Feng Y, Tian X, Wang B, Zhou Y: Oncogenic roles and drug target of CXCR4/CXCL12 axis in lung cancer and cancer stem cell. Tumour Biol 2016;37:8515-8528.

86 Wnorowski A, Jozwiak K: Homo- and hetero-oligomerization of $\beta 2$-adrenergic receptor in receptor trafficking, signaling pathways and receptor pharmacology. Cell Signal 2014;26:2259-2265.

87 Naka I, Hikami K, Nakayama K, Koga M, Nishida N, Kimura R, Furusawa T, Natsuhara K, Yamauchi T, Nakazawa M, Ataka Y, Ishida T, Inaoka T, Iwamoto S, Matsumura Y, Ohtsuka R, Tsuchiya N, Ohashi J: A functional SNP upstream of the beta-2 adrenergic receptor gene (ADRB2) is associated with obesity in Oceanic populations. Int J Obes (Lond) 2013;37:1204-1210.

88 Pignatti PF: Trends in pharmacogenomics of drugs used in the treatment of asthma. Pharmacol Res 2004;49:343-349.

89 Salopuro T, Lindstrom J, Eriksson JG, Valle TT, Hämäläinen H, Ilanne-Parikka P, Keinänen-Kiukaanniemi S, Tuomilehto J, Laakso M, Uusitupa M: Common variants in beta2- and beta3-adrenergic receptor genes and uncoupling protein 1 as predictors of the risk for type 2 diabetes and body weight changes. The Finnish Diabetes Prevention Study. Clin Genet 2004;66:365-367.

90 Wang H, Hao B, Chen X, Zhao N, Cheng G, Jiang Y, Liu Y, Lin C, Tan W, Lu D, Wei Q Jin L, Lin D, He F: Beta-2 adrenergic receptor gene (ADRB2) polymorphism and risk for lung adenocarcinoma: a case-control study in a Chinese population. Cancer Lett 2006;240:297-305.

-91 Hu P, He J, Liu S, Wang M, Pan B, Zhang W: $\beta 2$-adrenergic receptor activation promotes the proliferation of A549 lung cancer cells via the ERK1/2/CREB pathway. Oncol Rep 2016;36:1757-1763.

-92 Bando T, Fujimura M, Kasahara K, Ueno T, Matsuda T: Selective beta2-adrenoceptor agonist enhances sensitivity to cisplatin in non-small cell lung cancer cell line. Oncol Rep 2000;7:49-52.

93 Tantisira KG, Small KM, Litonjua AA, Weiss ST, Liggett SB: ALMolecular properties and pharmacogenetics of a polymorphism of adenylyl cyclase type 9 in asthma: interaction between beta-agonist and corticosteroid pathways. Human Molecular Genetics 2005;14:1671-1677.

94 Kim SH, Ye YM, Lee HY, Sin HJ, Park HS: Combined pharmacogenetic effect of ADCY9 and ADRB2 gene polymorphisms on the bronchodilator response to inhaled combination therapy. J Clin Pharm Ther 2011;36:399-405.

95 Alessandrini F, Cristofaro I, Di Bari M, Zasso J, Conti L, Tata AM: The activation of M2 muscarinic receptor inhibits cell growth and survival in human glioblastoma cancer stem cells. Int Immunopharmacol 2015;29:105-109. 


\section{Cellular Physiology Cell Physiol Biochem 2018;46:925-952

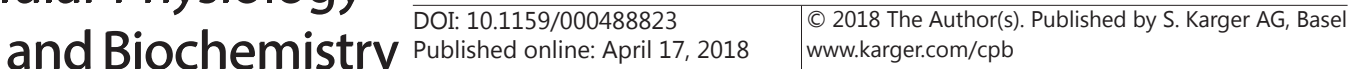

He et al.: Clinical Value of MicroRNA-210 in NSCLC

-96 Zhao Q Yue J, Zhang C, Gu X, Chen H, Xu L: Inactivation of M2 AChR/NF- $\mathrm{BB}$ signaling axis reverses epithelial-mesenchymal transition (EMT) and suppresses migration and invasion in non-small cell lung cancer (NSCLC). Oncotarget 2015;6:29335-29346.

-97 Zhao Q Gu X, Zhang C, Lu Q Chen H, Xu L: Blocking M2 muscarinic receptor signaling inhibits tumor growth and reverses epithelial-mesenchymal transition (EMT) in non-small cell lung cancer (NSCLC). Cancer Biol Ther 2015;16:634-643.

98 Seike M, Goto A, Okano T, Bowman ED, Schetter AJ, Horikawa I, Mathe EA, Jen J, Yang P, Sugimura H, Gemma A, Kudoh S, Croce CM, Harris CC: MiR-21 is an EGFR-regulated anti-apoptotic factor in lung cancer in neversmokers. Proc Natl Acad Sci U S A 2009;106:12085-12090.

-99 Tan X, Qin W, Zhang L, Hang J, Li B, Zhang C, Wan J, Zhou F, Shao K, Sun Y, Wu J, Zhang X, Qiu B, Li N, Shi S, Feng X, Zhao S, Wang Z, Zhao X, Chen Z, Mitchelson K, Cheng J, Guo Y, He J: A 5-microRNA signature for lung squamous cell carcinoma diagnosis and hsa-miR-31 for prognosis. Clin Cancer Res 2011;17:6802-6811.

100 Raponi M, Dossey L, Jatkoe T, Wu X, Chen G, Fan H, Beer DG: MicroRNA classifiers for predicting prognosis of squamous cell lung cancer. Cancer Res 2009;69:5776-5783.

101 Ohba T, Nagano H: A small-cell lung cancer subtype with good prognosis found by a three miRNA signature. https://www.ncbi.nlm.nih.gov/geo/query/acc.cgi?acc=GSE19945.

102 Nymark P, Guled M, Borze I, Faisal A, Lahti L, Salmenkivi K, Kettunen E, Anttila S, Knuutila S: Integrative analysis of microRNA, mRNA and aCGH data reveals asbestos- and histology-related changes in lung cancer. Genes Chromosomes Cancer 2011;50:585-597.

103 van Jaarsveld MT, Wouters MD, Boersma AW, Smid M, van Ijcken WF, Mathijssen RH, Hoeijmakers JH, Martens JW, van Laere S, Wiemer EA, Pothof J: DNA damage responsive microRNAs misexpressed in human cancer modulate therapy sensitivity. Mol Oncol 2014;8:458-468.

104 Bjaanaes MM, Halvorsen AR, Solberg S, Jørgensen L, , Dragani TA, Galvan A, Colombo F, Anderlini M, Pastorino U, Kure E, Børresen-Dale AL, Brustugun OT, Helland A: Unique microRNA-profiles in EGFRmutated lung adenocarcinomas. Int J Cancer 2014;135:1812-1821.

105 Arima C, Kajino T, Tamada Y, Imoto S, Shimada Y, Nakatochi M, Suzuki M, Isomura H, Yatabe Y, Yamaguchi T, Yanagisawa K, Miyano S, Takahashi T: Lung adenocarcinoma subtypes definable by lung developmentrelated miRNA expression profiles in association with clinicopathologic features. Carcinogenesis 2014;35:2224-2231.

106 Robles AI, Arai E, Mathé EA, Okayama H, Schetter AJ, Brown D, Petersen D, Bowman ED, Noro R, Welsh JA, Edelman DC, Stevenson HS, Wang Y, Tsuchiya N, Kohno T, Skaug V, Mollerup S, Haugen A, Meltzer PS, Yokota J, Kanai Y, Harris CC: An Integrated Prognostic Classifier for Stage I Lung Adenocarcinoma Based on mRNA, microRNA, and DNA Methylation Biomarkers. J Thorac Oncol 2015;10:1037-1048.

107 Gasparini P, Cascione L, Landi L, Carasi S, Lovat F, Tibaldi C, Alì G, D’Incecco A, Minuti G, Chella A, Fontanini G, Fassan M, Cappuzzo F, Croce CM: microRNA classifiers are powerful diagnostic/prognostic tools in ALK-, EGFR-, and KRAS-driven lung cancers. Proc Natl Acad Sci U S A 2015;112:14924-14929.

108 Jin Y, Liu YL, Lu SH: The miRNA expression profiles in three subtypes of lung carcinomas. https://www. ncbi.nlm.nih.gov/geo/query/acc.cgi?acc=GSE74190.

109 Yoshimoto T, Ishikawa Y. MicroRNA expression profiles of pulmonary and gastrointestinal carcinoid tumors. https://www.ncbi.nlm.nih.gov/geo/query/acc.cgi?acc=GSE77380.

110 Lu J, Getz G, Miska EA, Alvarez-Saavedra E, Lamb J, Peck D, Sweet-Cordero A, Ebert BL, Mak RH, Ferrando AA, Downing JR, Jacks T, Horvitz HR, Golub TR: MicroRNA expression profiles classify human cancers. Nature 2005;435:834-838.

111 Ma L, Huang Y, Zhu W, Zhou S, Zhou J, Zeng F, Liu X, Zhang Y, Yu J: An integrated analysis of miRNA and mRNA expressions in non-small cell lung cancers. PLoS One 2011;6:e26502.

112 Fujita Y, Yagishita S, Hagiwara K, Yoshioka Y, Kosaka N, Takeshita F, Fujiwara T, Tsuta K, Nokihara H, Tamura T, Asamura H, Kawaishi M, Kuwano K, Ochiya T: The clinical relevance of the miR-197/CKS1B/ STAT3-mediated PD-L1 network in chemoresistant non-small-cell lung cancer. Mol Ther 2015;23:717-727.

113 Keller A, Leidinger P, Borries A, Wendschlag A, Wucherpfennig F, Scheffler M, Huwer H, Lenhof HP, Meese E: miRNAs in lung cancer - studying complex fingerprints in patient's blood cells by microarray experiments. BMC Cancer 2009;9:353.

114 Patnaik SK, Yendamuri S, Kannisto E, Kucharczuk JC, Singhal S, Vachani A: MicroRNA expression profiles of whole blood in lung adenocarcinoma. PLoS One 2012;7:e46045. 


\section{Cellular Physiology Cell Physiol Biochem 2018;46:925-952

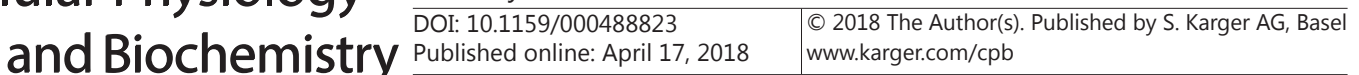

He et al.: Clinical Value of MicroRNA-210 in NSCLC

-115 Keller A, Leidinger P, Bauer A, Elsharawy A, Haas J, Backes C, Wendschlag A, Giese N, Tjaden C, Ott K, Werner J, Hackert T, Ruprecht K, Huwer H, Huebers J, Jacobs G, Rosenstiel P, Dommisch H, Schaefer A, Müller-Quernheim J, Wullich B, Keck B, Graf N, Reichrath J, Vogel B, Nebel A, Jager SU, Staehler P, Amarantos I, Boisguerin V, Staehler C, Beier M, Scheffler M, Büchler MW, Wischhusen J, Haeusler SF, Dietl J, Hofmann S, Lenhof HP, Schreiber S, Katus HA, Rottbauer W, Meder B, Hoheisel JD, Franke A, Meese E: Toward the bloodborne miRNome of human diseases. Nat Methods 2011;8:841-843.

116 Patnaik SK, Kannisto ED, Mallick R, Vachani A, Yendamuri S: Whole blood microRNA expression may not be useful for screening non-small cell lung cancer. PLoS One 2017;12:e0181926.

117 Keller A, Leidinger P, Vogel B, Backes C, ElSharawy A, Galata V, Mueller SC, Marquart S, Schrauder MG, Strick R, Bauer A, Wischhusen J, Beier M, Kohlhaas J, Katus HA, Hoheisel J, Franke A, Meder B, Meese E: miRNAs can be generally associated with human pathologies as exemplified for miR-144. BMC Med 2014;12:224.

118 Leidinger P, Galata V, Backes C, Stähler C, Rheinheimer S, Huwer H, Meese E, Keller A: Longitudinal study on circulating miRNAs in patients after lung cancer resection. Oncotarget 2015;6:16674-16685.

119 Liu X, Qu L: Gene expression-signatures for non-small cell lung cancer patients with different EGFR muational status. https://www.ncbi.nlm.nih.gov/geo/query/acc.cgi?acc=GSE93300.

120 Lodes MJ, Caraballo M, Suciu D, Munro S, Kumar A, Anderson B: Detection of cancer with serum miRNAs on an oligonucleotide microarray. PLoS One 2009;4:e6229.

121 Godrey A, Xu Z, Sieber S, Hayes N, Rivera P, Taylor J: Serum miRNA expression is associated with lung cancer in a case-control study and normalizes following surgical resection. https://www.ncbi.nlm.nih.gov/ geo/query/acc.cgi?acc=GSE46729. 